\title{
Nogo-A Stabilizes the Architecture of Hippocampal Neurons
}

\author{
Marta Zagrebelsky, ${ }^{1}$ Rüdiger Schweigreiter, ${ }^{2}$ Christine E. Bandtlow, ${ }^{2}$ Martin E. Schwab, ${ }^{3}$ and Martin Korte ${ }^{1}$ \\ ${ }^{1}$ Zoological Institute, Division of Cellular Neurobiology, University of Braunschweig, D-38106 Braunschweig, Germany, ${ }^{2}$ Division of Neurobiochemistry, \\ Innsbruck Medical University, A-6020 Innsbruck, Austria, and ${ }^{3}$ Brain Research Institute, University of Zurich and Department of Biology, Swiss Federal \\ Institute of Technology Zurich, CH-8057 Zurich, Switzerland
}

\begin{abstract}
Although the role of myelin-derived Nogo-A as an inhibitor of axonal regeneration after CNS injury has been thoroughly described, its physiological function in the adult, uninjured CNS is less well known. We address this question in the hippocampus, where Nogo-A is expressed by neurons as well as oligodendrocytes. We used $21 \mathrm{~d}$ in vitro slice cultures of neonatal hippocampus where we applied different approaches to interfere with Nogo-A signaling and expression and analyze their effects on the dendritic and axonal architecture of pyramidal cells. Neutralization of Nogo-A by function-blocking antibodies induced a major alteration in the dendrite structure of hippocampal pyramidal neurons. Although spine density was not influenced by Nogo-A neutralization, spine type distribution was shifted toward a more immature phenotype. Axonal complexity and length were greatly increased. Nogo-A KO mice revealed a weak dendritic phenotype resembling the effect of the antibody treatment. To discriminate a possible cell-autonomous role of Nogo-A from an environmental, receptor-mediated function, we studied the effects of short hairpin RNA-induced knockdown of Nogo-A or NgR1, a prominent Nogo-A receptor, within individual neurons. Knockdown of Nogo-A reproduced part of the dendritic and none of the spine or axon alterations. However, downregulation of NgR1 replicated the dendritic, the axonal, and the spine alterations observed after Nogo-A neutralization. Together, our results demonstrate that Nogo-A plays a major role in stabilizing and maintaining the architecture of hippocampal pyramidal neurons. Mechanistically, although the majority of the activity of Nogo-A relies on a receptor-mediated mechanism involving $\mathrm{NgR} 1$, its cell-autonomous function plays a minor role.
\end{abstract}

\section{Introduction}

In the adult nervous system, a complex balance between plasticity and stability processes controls the acquisition, storage, and clearance of information in a dynamic but controlled manner. Dendritic architecture as well as the number and shape of dendritic spines strongly influence neuronal function and are in turn influenced by neuronal activity (Yuste and Bonhoeffer, 2004). Plastic changes in the structure of neurons have been correlated with activity-dependent information storage processes (Yuste and Bonhoeffer, 2001). The structural remodeling shaping developing and mature neuronal connections includes growth and retraction of neurites, dendritic spines, and synapses. During this process, several environmental cues regulate axon and dendrite growth (Lom and Cohen-Cory, 1999; McAllister, 2000; Huber et al., 2003) and retraction (Buffo et al., 2000; Liu et al., 2006). Among the latter, the myelin-associated protein Nogo-A has been identified as an inhibitor of neurite outgrowth in the adult CNS (Caroni and Schwab, 1988; Chen et al., 2000), and its func-

\footnotetext{
Received Feb. 28, 2010; revised July 28, 2010; accepted Aug. 2, 2010.

This work was supported by the Deutsche Forschungsgemeinschaft Grant ZA 554/2-1 (M.Z., M.K.), by the Swiss National Science Foundation (M.E.S.), and by Fonds zur Förderung der Wissenschaftlichen Forschung Grant W1206 (C.E.B.). We thank Diane Mundil and Oliver Weinman for their outstanding technical assistance in preparing the organotypic hippocampal cultures and in performing the Nogo-A immunohistochemistry. We are especially grateful to Dr. Andreas Holz for performing the Nogo-A in situ hybridization, Stella Kramer for performing the Western blots in nogo-A knock-out mice, and Steffen Kistner for the Western blot analysis of the RNAi approach.

Correspondence should be addressed to Dr. Martin Korte, Division of Cellular Neurobiology, Zoological Institute, Technische Universität Braunschweig, Spielmannstrasse 7, D-38106 Braunschweig, Germany. E-mail: m.korte@tu-bs.de.

DOI:10.1523/JNEUROSCI.1044-10.2010

Copyright $\odot 2010$ the authors $\quad 0270-6474 / 10 / 3013220-15 \$ 15.00 / 0$
}

tion in preventing plastic growth and regeneration of injured CNS axons has been thoroughly described (Schwab, 2004).

Although numerous studies demonstrate a crucial role of Nogo-A in preventing repair processes after a lesion in the spinal cord and specific CNS regions, only few studies addressed the physiological role of Nogo-A. During development, Nogo-A influences migration and neurite outgrowth of cortical neurons (Mingorance-Le Meur et al., 2007), conducts corticospinal axons growing along the spinal cord (Schwab and Schnell, 1991), and regulates the progressive restriction of plasticity (Kapfhammer and Schwab, 1994b; Gianola et al., 2003; McGee et al., 2005). In the mature CNS, both known receptors for Nogo-A, Nogo-66 receptor 1 (NgR1) and the paired Ig-like receptor B (PirB), modulate activity-dependent synaptic plasticity. In ngrl (McGee et al., 2005) and in pirB knock-out mice (Syken et al., 2006), ocular dominance plasticity continues after the end of the critical period, suggesting that NgR1 and PirB signaling contribute to stabilizing the neural circuitry and to temporally limit experiencedependent plasticity. In the mouse cerebellum, overexpression of Nogo-A leads to an age-dependent destabilization and loss of synapses of Purkinje cells (Aloy et al., 2006). Furthermore, NgR1 signaling has been shown to regulate activity-dependent synaptic strength in hippocampal CA1 neurons (Lee et al., 2008).

Although Nogo-A was first identified as a myelin-associated protein expressed in mature oligodendrocytes (Caroni and Schwab, 1988; Chen et al., 2000), it was recently described in developing and mature neurons in several CNS areas (Josephson et al., 2001; Huber et al., 2002; Hunt et al., 2002). Although myelination is low in highly plastic areas of the mature CNS 
(Kapfhammer and Schwab, 1994a), neurons in these regions, such as pyramidal cells of the hippocampus and neurons in the olfactory bulb, express Nogo-A (Huber et al., 2002; Mingorance et al., 2004). This observation suggests the interesting possibility of a specific role of the neuronal Nogo-A during plastic processes.

Here, we report a novel physiological function of Nogo-A in the hippocampus. We found Nogo-A to be involved in stabilizing the dendritic architecture of hippocampal neurons by a combined cell-autonomous and receptor-mediated mechanism.

\section{Materials and Methods}

Preparation of hippocampal slice cultures. Hippocampal organotypic cultures were prepared from postnatal day 5 (P5) C57BL/6 wild-type (WT) mice or nogo-A knock-out (KO) mice (Simonen et al., 2003) following the method of Stoppini et al. (1991). Briefly, the hippocampus was dissected in ice-cold sterile Geys balanced salt solution (GBSS) containing $0.5 \mathrm{ml}$ of kynurenic acid ( $100 \mathrm{~mm}$ stock solution) and $0.5 \mathrm{ml}$ of glucose (50\% stock solution) and adjusted to $\mathrm{pH}$ 7.2. The hippocampi were then sliced transversely at a thickness of $400 \mu \mathrm{m}$ using a tissue chopper (McIllwain). The slices were plated onto Millicells CM membrane inserts (Millipore) and cultivated in a $37^{\circ} \mathrm{C}, 5 \% \mathrm{CO}_{2}, 99 \%$ humidity incubator. The slices were maintained in medium containing 50\% BME (Eagle, with Hanks salts without glutamine), 25\% HBSS, $1 \mathrm{ml}$ of glucose (50\%), 25\% donor equine serum (HyClone), and $0.5 \mathrm{ml}$ of L-glutamine $(200 \mathrm{~mm}$ stock solution) with medium changes every third day. To reduce the number of non-neuronal cells, the slices were treated for $24 \mathrm{~h}$ with a mixture of antimitotic drugs (cytosine arabinoside, uridine, and fluorodeoxyuridine; $10^{-6}-10^{-7} \mathrm{M}$ each; Sigma-Aldrich).

Dissociated hippocampal neurons, transfection, and Nogo-A $\Delta 20$ treatment. Primary hippocampal cultures were prepared from C57BL/6 mice (embryonic day 18). The hippocampi were dissected in cold GBSS, incubated for $30 \mathrm{~min}$ in trypsin/EDTA at $37^{\circ} \mathrm{C}$, and then mechanically dissociated. Cells were plated at high density $\left(10^{5} /\right.$ well $)$ on poly-L-lysine-coated coverslips $(13 \mathrm{~mm})$ and kept in Neurobasal medium (Invitrogen) supplemented with $2 \%$ B27 (Invitrogen) and $0.5 \mathrm{~mm}$ Glutamax at $37^{\circ} \mathrm{C}, 5 \% \mathrm{CO}_{2}$, and $99 \%$ humidity. Hippocampal neurons were transfected with a farnesylated form of enhanced green fluorescent protein (fEGFP) at $24 \mathrm{~d}$ in vitro (DIV) using Lipofectamine 2000 following the manufacturer's instructions in Neurobasal medium without B27.

Twenty-four hours after transfection, the Nogo-A- $\Delta 20$ fragment was applied directly into the medium $(5 \mu \mathrm{g} / \mathrm{ml})$. As a control, an equal volume of distilled water was added to the medium. The cultures were fixed 15 min after the Nogo-A $\Delta-20$ application in a $4 \%$ paraformaldehyde (PFA) solution (in $0.1 \mathrm{M}$ phosphate buffer), washed, and mounted with an antifading water-based mounting medium (Sigma-Aldrich).

Plasmids and reagents. To visualize the dendrites and dendritic spines of pyramidal cells within WT and nogo-A KO-derived organotypic cultures, we biolistically transfected individual neurons with fEGFP, specifically targeted to the membrane, driven by the cytomegalovirus (CMV) promoter (Clontech). For selective knockdown of Nogo-A and NgR1, short interfering RNAs were custom synthesized targeting nucleotide position 1084 of mouse Nogo-A (AAA GAT GCA TGC TTA TGA AAC; GenBank accession number NM_194054) and nucleotide position 329 of mouse NgR1 (TGC TAC AAT GAG CCC AAG GTA; GenBank accession number NM_022982) and inserted into the pSuperior-neo-GFP plasmid (OligoEngine) (Brummelkamp et al., 2002). As controls for RNA interference (RNAi), the following two short hairpin RNAs (shRNAs) were used: a mismatch shRNA directed against Nogo-A and an unrelated shRNA directed against RFP (Xie et al., 2006). As we could not detect any significant differences for dendrite complexity, spine density and type distribution, as well as axonal length and complexity between CA1 and CA3 pyramidal neurons expressing fEGFP only or the control shRNAs (supplemental Fig. 3, Tables S2, S4, available at www.jneurosci.org as supplemental material), the latter were used in all parts of the following description. The efficiency and specificity of the shRNA constructs were checked by Western blot in rat B104 cells (endogenously expressing Nogo-A and Nogo-B) for the Nogo-A-specific shRNA or in HEK cells stably transfected to express V5-NgR1/HA-p $75^{\text {NTR }}$ for the NgR1 shRNA.
Furthermore, the efficiency of downregulation achieved with these constructs was analyzed in dissociated hippocampal neurons after Nogo-A or NgR1 immunohistochemistry. Briefly, the 21 DIV dissociated hippocampal neurons were fixed in 4\% PFA $8 \mathrm{~d}$ after transfection with Nogo-A or NgR1 shRNAs, blocked with $10 \%$ goat serum in PBS with $0.2 \%$ Triton X-100, and incubated overnight with the primary antibodies: the polyclonal anti-Nogo-A antiserum Laura (1:300) (Oertle et al., 2003) and a monoclonal antibody against NgR1 (1:50; R\&D Systems). The cells were then probed with fluorescence-conjugated secondary antibodies coupled to Cy3 (1:400; Jackson ImmunoResearch Laboratories). The images were acquired with a Zeiss LSM confocal microscope; the mean pixel intensity at the cell body was measured with Image J and compared between transfected (EGFP-expressing) and untransfected cells. Nogo-A as well as Nogo-B were cloned into a myc-tag encoding pcDNA 3.1. The overexpression of Nogo-A and Nogo-B was controlled by positivity to a post hoc immunohistochemistry for the myc tag in fEGFP-expressing cells. Briefly, the cultures were fixed in $4 \%$ PFA overnight at $4^{\circ} \mathrm{C}$, blocked for $1 \mathrm{~h}$ in $0.2 \%$ Triton $\mathrm{X}-100,10 \%$ horse serum in 0.1 м PBS. The primary antibody (anti-myc, clone 9E10, was a gift from Prof. Dieter Fürst, University of Bonn, Bonn, Germany) was diluted 1:1000 in the blocking solution, and the cultures were incubated overnight at $4^{\circ} \mathrm{C}$. The secondary antibody, anti-mouse-Cy3 (Jackson ImmunoResearch Laboratories) was diluted 1:400 in PBS and the slices incubated $3 \mathrm{~h}$ at room temperature. The cultures were then washed and mounted with an antifading water-based mounting medium (SigmaAldrich) and imaged.

Antibody treatment. The mouse monoclonal antibody $11 \mathrm{C} 7$ was raised against a peptide corresponding to the rat Nogo-A sequence amino acids 623-640 (Oertle et al., 2003). The antibody is monospecific for Nogo-A in Western blots (Oertle et al., 2003; Dodd et al., 2005) and shows no cross-reactivity with other Nogo variants (Oertle et al., 2003; Dodd et al., 2005). Its Nogo-A function-blocking ability has been confirmed in vitro and in vivo (Wiessner et al., 2003; Liebscher et al., 2005). The antibody was applied directly into the medium $(5 \mu \mathrm{g} / \mathrm{ml})$, and the treatment was repeated twice during the $4 \mathrm{~d}$ of application. As a control, a mouse IgG1 (mIgG1 against wheat auxin) was used at the same concentration and for the same time period as the 11C7 antibody. With regard to the controls, unless stated in the text, we could not detect any significant differences between not treated and control mIgG1-treated pyramidal neurons in CA1 and CA3 (supplemental Fig. 2, Tables S1, S3, available at www. jneurosci.org as supplemental material) for dendrite complexity, spine density and type distribution, as well as axonal length and complexity. Therefore, in the following description, the two control conditions were pooled. The spine type distribution was compared with the mIgG1 control antibody treatment.

Particle-mediated gene transfer. Hippocampal slice cultures were transfected using the particle-mediated gene transfer device Helios Gene Gun System (Bio-Rad) after 21 DIV. Plasmids were purified on a QIAGEN column and precipitated onto $0.6 \mu \mathrm{m}$ gold microcarrier particles according to the Helios Gene Gun (Bio-Rad) instruction manual. For cotransfection, the DNA loading ratio was one part fEGFP to three parts of the other vector (Nogo-A or NgR1 shRNA and Nogo-Amyc) for a total of 2 $\mu \mathrm{g}$ of DNA/mg gold. For the expression of fEGFP alone, the plasmid total amount was also $2 \mu \mathrm{g}$ of DNA/mg gold. The gold beads coated with expression plasmids were then propelled from plastic tubing bullets onto the slices by a rapid helium burst of $80-100$ psi. The gold beads exited the gene gun at $\sim 1 \mathrm{~cm}$ above the slices and went through a filter with a pore size of $3 \mu \mathrm{m}$ to prevent big clusters of beads from reaching the slices. Four days after transfection, the slices were fixed overnight with $4 \%$ PFA, washed, mounted with an antifading water-based mounting medium (Sigma-Aldrich), and imaged.

Neuron selection. The delivery of a single gold particle carrying fEGFP under the control of the CMV promoter resulted in the intense labeling of the entire dendritic arbor (see Fig. $1 A, C$ ) as well as of all dendritic spines (see Fig. 2C,D) of individual pyramidal neurons. Small numbers of individual pyramidal neurons were transfected in each culture allowing to easily follow the complete dendritic processes of each labeled neuron. Only nonoverlapping labeled neurons were selected for our analysis allowing for an unambiguous reconstruction of the entire dendritic tree. 
Reliable cotransfection was achieved by coating gold particles with a 3:1 mixture of DNA constructs. Overexpression of the Nogo-A shRNA or of the control shRNA in fEGFP-expressing pyramidal cells was confirmed by the expression of EGFP in the cell body cytoplasm. All analyzed neurons derived from 25 DIV cultures prepared from P5 to P6. Anatomical criteria were used to identify a neuron as a dentate gyrus granule cell, CA1 or CA3 pyramidal cell, or interneuron. Because of the significant differences between CA1 and CA3 pyramidal neurons both in their dendritic arbor length and complexity (supplemental Fig. 1, available at www. jneurosci.org as supplemental material), these neurons were analyzed separately. Only CA1 and CA3 pyramidal cells completely filled with fEGFP and not showing any sign of degeneration were selected for imaging.

Neuronal imaging and analysis. Neurons selected for analysis were imaged with an ApoTome imaging system (Zeiss). Each neuron was first imaged using a $20 \times$ objective [1.25 numerical aperture (NA)] and $z$-sectioned at $0.975 \mu \mathrm{m}$ increments. The raw data were then used for the Sholl analysis (Sholl, 1953) of dendritic length and complexity. The neurons were traced using the Neurolucida software (MicroBrightField), and the Sholl analysis was obtained with Neuroexplorer software (MicroBrightField), calculating the cumulative number of dendritic intersections at $10 \mu \mathrm{m}$ interval distance points starting from the cell body. The analysis of the number of dendrite crossings was performed separately for basal and apical dendrites. We also calculated the total number of crossings for each cell as an index for total dendritic complexity. The same images were used to trace the axons of CA3 pyramidal cells. The neurons were both imaged and analyzed in a blind fashion. Spine density was measured separately for basal, midapical, and distal-apical dendrites. The selected dendrite segments were imaged using a $63 \times$ objective $(1.32$ $\mathrm{NA}$ ) and $z$-sectioned at $0.475 \mu \mathrm{m}$ increments. The number of spines and the dendritic length was counted on three-dimensional stacks using the Neuroexplorer software (MicroBrightField). Care was taken to ensure that each spine was counted only once by following its course through adjacent $z$-sections. The number of spines was normalized per micrometer of dendritic length. Spine density counts were performed blindly. In the two control conditions (nontreated fEGFP-labeled, and control mIgG1-treated fEGFP-labeled neurons), spine density values (see Fig. $2 A, B$; supplemental Table S1, available at www.jneurosci.org as supplemental material) did not differ; they were, however, slightly higher than those reported previously for hippocampal neurons in organotypic cultures (Tyler and Pozzo-Miller, 2001; Zagrebelsky et al., 2005). This finding could be attributable to the higher resolution obtained with the expression of the membrane targeted fEGFP compared with the cytoplasmic EGFP used in previous studies.

Classification of spines. Dendritic spines were classified according to two main criteria (Harris et al., 1992; Koh et al., 2002; Zagrebelsky et al., 2005). First, their length was measured from their base at the dendrite to the tip of their head. In addition, spine shape was defined by the ratio between the minimum ( $\min$ ) and the maximum (max) diameters of the spine neck and head, respectively, allowing to classify them following standard categories (Peters and Kaisrman-Abramof, 1969), as stubby (type 1), mushroom (type 2), and thin (type 3 ). We were thus able to distinguish three main spine subtypes: stubby in which the length is $<1$ $\mu \mathrm{m}$ and the $\max _{\text {head }} / \min _{\text {neck }}$ ratio is $<1.5$, thin in which the max $\operatorname{mead}_{\text {hea }} /$ $\min _{\text {neck }}$ ratio is $<1.5$ and the length $\geq 1 \mu \mathrm{m}$, and mushroom in which the $\max _{\text {head }} / \min _{\text {neck }}$ ratio is $\geq 1.5$ (independent of their length). This method has the advantage that the spine categorization is determined by objective criteria.

Statistical analysis. The statistical analysis was performed using Microsoft Excel or GraphPad Prism. The data obtained were compared between two different experimental conditions using an unpaired twotailed Student $t$ test for the Sholl analysis and spine density measurement. Data regarding the spine type distribution were analyzed using a two-way ANOVA followed by a Bonferroni post test. Values of $p<0.05$ were considered significant. The Sholl analysis data were tested by applying a two-tailed Student $t$ test point by point. All data shown are presented as mean \pm SEM.

Riboprobe synthesis and in situ hybridization. A 729 bp EcoRI/PvuII fragment of a Nogo-A cDNA (accession number AY114152) was inserted in the pSP71 vector allowing the strand-specific generation of digoxigenin-labeled riboprobes as previously described (Holz et al., 1996). NgR1 ribroprobes were made from full-length cDNA clone IRAVp968G10118D (ImaGenes) as described by Fournier et al. (2001). In situ hybridization on 25 DIV slice cultures was performed as previously described (Zagrebelsky et al., 2005). Briefly, the tissue was fixed with $4 \%$ PFA in phosphate buffer, acetylated, and permeabilized. After incubation in hybridization buffer [ $50 \%$ formamide, $5 \times$ SSC, $2 \%$ blocking reagent (Roche)], the tissue was hybridized with either the sense or antisense Nogo-A and $\mathrm{NgR} 1$ riboprobes at $70^{\circ} \mathrm{C}$ for $16 \mathrm{~h}$. After stringent washes in $0.2 \times \mathrm{SSC}$ at $70^{\circ} \mathrm{C}$, specifically bound riboprobes were detected by an alkaline phosphatase-conjugated anti-digoxigenin antibody (Roche) and a NBT (nitroblue tetrazolium)/BCIP (5-bromo-4-chloro3 -indolyl phosphate) color reaction. Before photomicroscopic analysis, the tissue was counterstained with DAPI $\left(4^{\prime}, 6^{\prime}\right.$-diamidino-2-phenylindole) and mounted with a water-based mounting medium.

Nogo-A and NgR1 immunofluorescence and densitometry. Nogo-A and $\mathrm{NgR} 1$ proteins were detected in postnatal day 28 hippocampus by immunohistochemistry using the polyclonal anti-Nogo-A antiserum Laura (Oertle et al., 2003) and a goat anti-NgR1 polyclonal antibody (R\&D Systems), respectively. Briefly, the brains were fixed by heart perfusion with ice-cold fixative (4\% PFA and $15 \%$ saturated picric acid in $0.15 \mathrm{M}$ phosphate buffer, $\mathrm{pH} 7$ ). Brains were removed immediately, postfixed in the same fixative for $4-18 \mathrm{~h}$ at $4^{\circ} \mathrm{C}$, and cryoprotected before freezing. Coronal sections $(40 \mu \mathrm{m})$ were cut with a cryostat. We improved the staining sensitivity by applying a heated antigen retrieval step in $0.1 \mathrm{M}$ Tris buffer, $\mathrm{pH} 8.0$, at $80^{\circ} \mathrm{C}$ for $10-20$ min to unmask the Nogo-A and for 10 min to unmask the NgR1 antigen. Free-floating sections from nogo$A^{-1-}$ and nogo- $A^{+/+}$mice were batch-processed under identical conditions to minimize staining variability. Sections were incubated overnight at $4^{\circ} \mathrm{C}$ with primary antibodies diluted 1:300 in PBS containing TNB blocking solution and $0.05 \%$ Triton X-100. Sections were then probed with fluorescence-conjugated secondary antibodies coupled to Cy2 (Jackson ImmunoResearch Laboratories). Images were acquired using a cooled CCD camera (CoolSnap HQ; Photometrics) attached to a Zeiss Axiophot microscope (Zeiss) and collected using computer-assisted image analysis software (MCID; Elite software, version 7.0; Imaging Research). For densitometry, the mean gray value from four animals for each region was determined using ImageJ software after defining a threshold that was kept identical throughout the analysis. The mean gray value of the CA1 WT animals was set to the relative OD 1.0.

In some instances to clearly label the pyramidal cell layer, a NeuN (Millipore) costaining was performed with fluorescence-conjugated secondary antibodies coupled to Cy3 (Jackson ImmunoResearch Laboratories). Images were taken with a spectral confocal microscope (Leica TCS SP2; Leica confocal software, version 2.61).

Nogo-B and NgR1 Western blot. Nogo-B and NgR1 expression levels in P28 WT and nogo-A KO hippocampi were analyzed by Western blot. Briefly, mouse hippocampi were homogenized and lysed in CHAPS lysis buffer (50 mм $\mathrm{NaH}_{2} \mathrm{PO}_{4}, \mathrm{pH} 8.0,150 \mathrm{~mm} \mathrm{NaCl}, 0.5 \%$ CHAPS). The samples were then adjusted to similar protein concentration, separated by SDS-PAGE, and blotted onto nitrocellulose. Fractions were analyzed using antibodies specific for Nogo-A (1:500; 11C7), Nogo-B (1:300; Bianca AS), NgR1 (1:500; R\&D Systems), and $\beta$-tubulin (1:1000; Sigma-Aldrich).

\section{Results}

\section{Nogo-A neutralization affects the dendritic structure of hippocampal pyramidal neurons}

Nogo-A is expressed by mature neurons and oligodendrocytes of the hippocampus (Huber et al., 2002; Craveiro et al., 2008). To examine a potential role of Nogo-A in modulating the dendritic architecture of pyramidal neurons we treated 3-week-old, differentiated WT hippocampal organotypic slice cultures with an anti-Nogo-A function blocking antibody. CA1 and CA3 hippocampal pyramidal cells were visualized by the expression of membrane targeted fEGFP in a small, random population of neurons by biolistic transfection. When fEGFP-expressing CA1 py- 

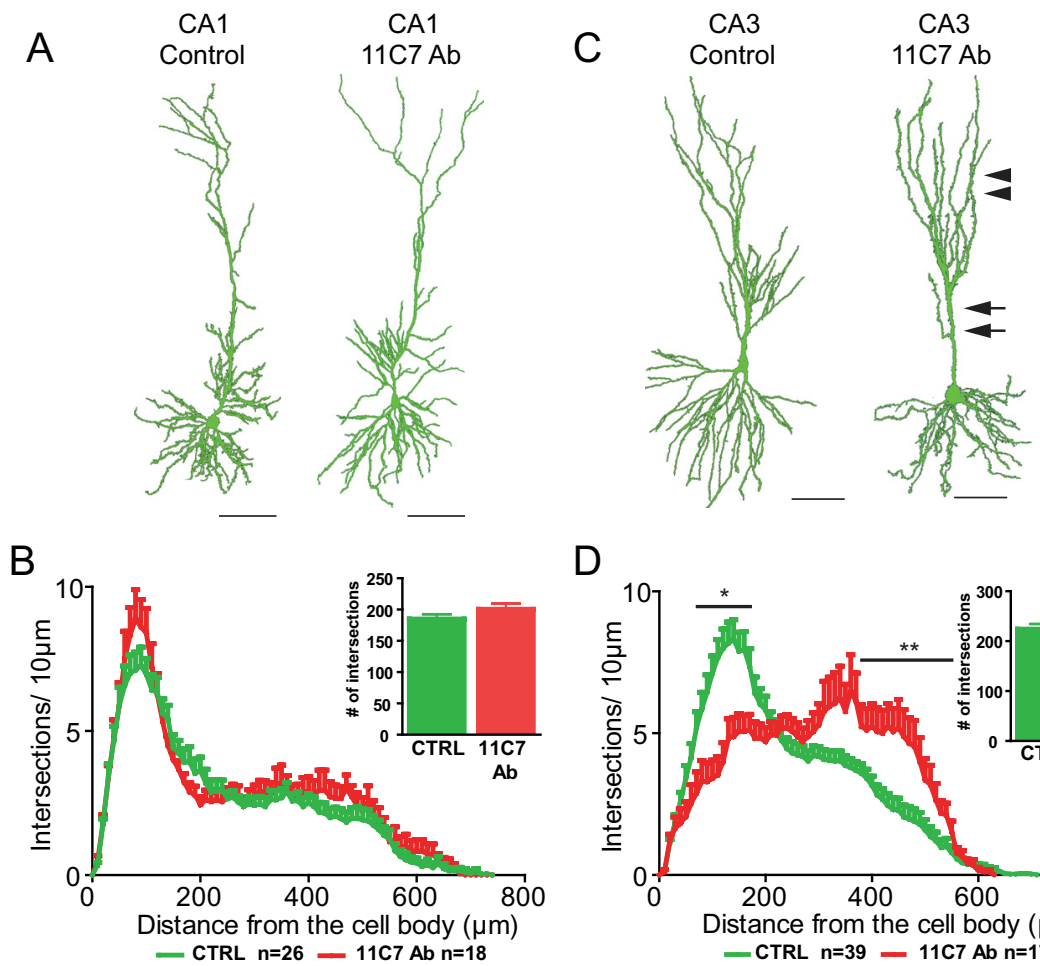

D
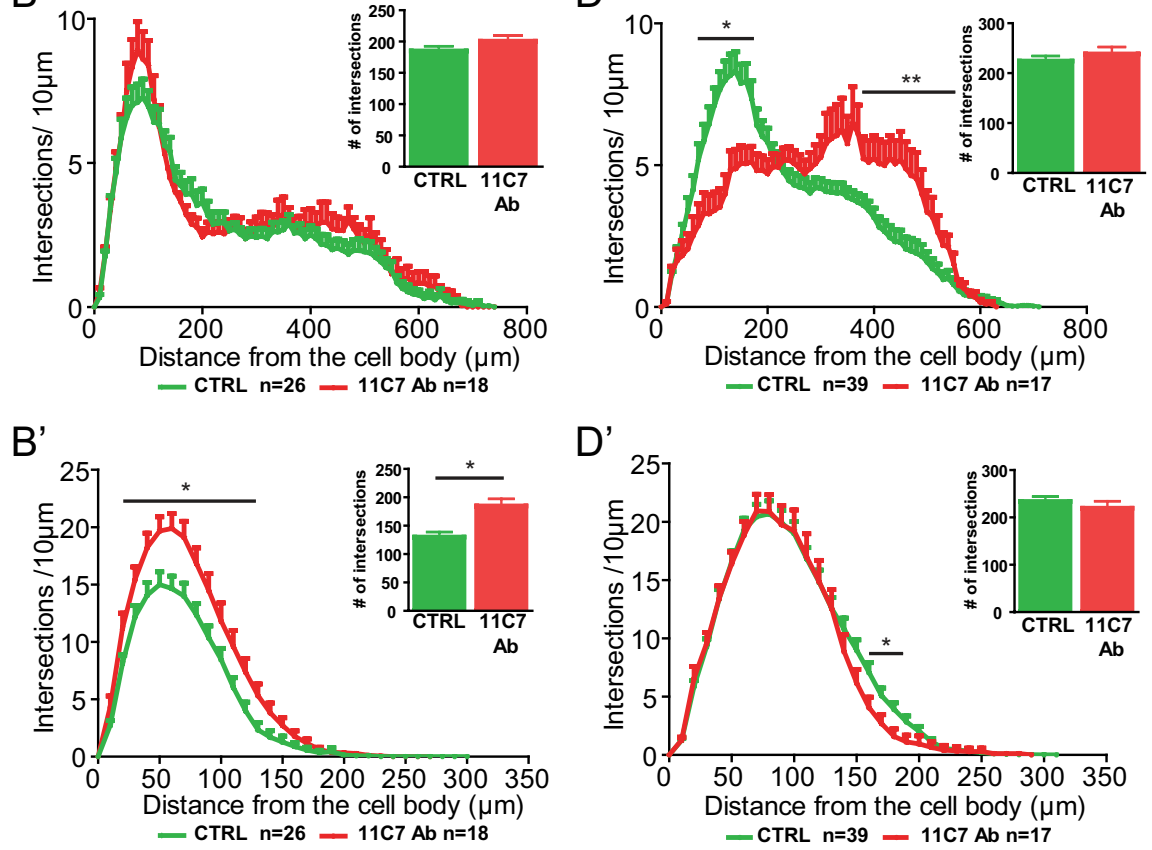

Figure 1. Nogo-A neutralization affects dendritic structure of hippocampal pyramidal neurons. $A$, ApoTome image consisting of stacks of multiple optical sections showing the normal morphology of fEGFP-labeled control (left) and 11C7 Ab-treated CA1 hippocampal pyramidal neurons. Note the complete filling of dendrites as well as the absence of any sign of degeneration. Scale bar, $100 \mu \mathrm{m} . \boldsymbol{B}, \boldsymbol{B}^{\prime}$, Sholl analysis comparing the apical $(\boldsymbol{B})$ and basal ( $\left.\boldsymbol{B}^{\prime}\right)$ dendrite of control and 11C7 Ab-treated CA1 pyramidal neurons. The asterisks indicate $p<0.05$. The insets show the total dendritic of the apical (above) and basal (below) dendrites of control and $11 C 7$ Ab-treated CA1 neurons, respectively. C, ApoTome images showing a representative example of a fEGFPexpressing control (left) and $11 C 7$ Ab-treated (right) CA3 pyramidal neuron. Scale bar, $100 \mu \mathrm{m}$. Note the differences in dendritic complexity: the lower complexity proximally (arrows) and the higher complexity distally (arrowheads) of the $11 \mathrm{C} 7 \mathrm{Ab}$-treated neuron. $\boldsymbol{D}, \boldsymbol{D}^{\prime}$, Sholl analysis comparing the apical $(\boldsymbol{D})$ and basal $\left(\boldsymbol{D}^{\prime}\right)$ dendrite of control and $11 \mathrm{C}$ Ab-treated CA3 pyramidal neurons. The insets show the total dendritic of respectively the apical (above) and basal (below) dendrites of control and 11C7 $A b$-treated CA3 neurons. The asterisks indicate $p<0.05$. Error bars indicate SEM.

ramidal neurons treated with the Nogo-A blocking antibody $11 \mathrm{C} 7 \mathrm{Ab}$ were qualitatively compared with control CA1 pyramidal neurons, no apparent alterations in dendritic orientation or gross neuronal architecture could be detected (Fig. 1A). Accordingly, total complexity of the apical dendrites was not significantly different in 11C7 antibody-treated versus control CA1 pyramidal cells (Fig. $1 B$, inset) (control vs $11 \mathrm{C} 7 \mathrm{Ab}, p=0.69 ; 11 \mathrm{C} 7 \mathrm{Ab}, n=$ 18; control, $n=26$ ). Sholl analysis performed by plotting the number of intersections against the distance from the cell body of the CA1 apical dendrites showed a slight, nonsignificant increase in complexity on 11C7 antibody treatment (Fig. $1 B$, Table 1 ). On the contrary, when compared with control CA1 cells, the basal dendrites of $11 \mathrm{C} 7$ antibody-treated cells showed a significant increase in total complexity (Fig. $1 B^{\prime}$, inset) (11C7 Ab vs control, $p<0.05)$, most prominently within the proximal portion (Fig. $1 B$, Table 1) $(p<0.05$ between 20 and $140 \mu \mathrm{m}$ from the cell body).

11C7 Nogo-A blocking antibody treatment induced a much stronger alteration in CA3 than in CA1 pyramidal cells, particularly at the level of the apical dendrite (Fig. 1C). Although the proximal portion of the apical dendrite showed notably less branches (arrows), dendritic complexity in the middistal portion was remarkably increased (arrowheads) when compared with control CA3 cells (Fig. 1C). In addition, in a few neurons, the most distal portion of the apical dendrite was decorated by short and highly branched sprouts emerging from the terminal dendrites (data not shown). Total dendritic complexity, however, was not significantly different between 11C7 antibody-treated and control cells (Fig. $1 D$, inset) (11C7 $\mathrm{Ab}, n=17$; control, $n=39 ; p=0.83$ ), suggesting that the proximal reduction in dendritic complexity was completely compensated by its increase distally. The Sholl analysis confirmed the qualitative impression: a highly significant decrease in complexity of the apical dendrites was observed between 50 and $200 \mu \mathrm{m}$ from the cell body of the 11C7 antibody-treated CA3 cells (Fig. $1 D$, Table 1$)(n=17)$ versus the same portion of CA3 control cells (Fig. $1 D)(n=39$; $p<0.05$ between 50 and $60 \mu \mathrm{m}$ and between 180 and $200 \mu \mathrm{m}$, and $p<0.001$ between 70 and $170 \mu \mathrm{m})$. Moreover, dendrite complexity was significantly higher between 370 and $530 \mu \mathrm{m}$ from the cell body in the Nogo-A antibody-treated CA3 cells (Fig. $1 D$, Table 1$)(p<0.05$ at $370 \mu \mathrm{m}$, between 400 and $420 \mu \mathrm{m}$, between 450 and $530 \mu \mathrm{m}$, and $p<0.001$ between 430 and $440 \mu \mathrm{m}$ ). Interestingly, the increase in complexity of the CA3 apical dendrites occurs specifically within the stratum radiatum, where recurrent collaterals of the CA3 pyramidal cell axons form their synapses. Contrary to the very strong and complex phenotype observed at the CA3 cell apical dendrites, the basal dendrites showed a mild alteration in response to Nogo-A antibody treatment. Although total complexity was unaltered when compared with control cells (Fig. $1 D^{\prime}$ ) (control vs $11 \mathrm{C} 7 \mathrm{Ab}, p=0.31$ ), a significant reduction in dendritic complexity could be observed only in a limited portion of the basal dendrites of 11C7-treated cells $(p<0.05$ between 160 and $190 \mu \mathrm{m}$ from the cell body).

Together, these results demonstrate that Nogo-A is part of the molecular network controlling the branching pattern of hippocampal pyramidal cell dendrites. Furthermore, the specificity of this influence is supported by the fact that the dendrites of CA3 pyramidal cells are more affected by the Nogo-A neutralization than those of CA1 cells. 


\begin{tabular}{|c|c|c|c|}
\hline Treatment & Axon & Dendrites & Dendritic spines \\
\hline \multicolumn{4}{|l|}{ CA1 } \\
\hline $11 c 7 \mathrm{Ab}$ & - & $\begin{array}{l}\text { Basal complexity }++ \\
\text { Apical complexity }=\end{array}$ & $\begin{array}{l}\text { Density }= \\
\text { Type }+ \text { type I (distal-apical) }\end{array}$ \\
\hline$n \circ g \circ A^{-1-}$ & - & $\begin{array}{l}\text { Basal complexity = } \\
\text { Apical complexity + (distal) }\end{array}$ & Density - (distal-apical) \\
\hline \multicolumn{4}{|l|}{ CA3 } \\
\hline $11 \mathrm{c} 7 \mathrm{Ab}$ & $\begin{array}{l}\frac{\text { Length }++}{\text { Complexity }++} \\
\text { 이 }\end{array}$ & $\begin{array}{l}\text { Basal - (distal) } \\
\begin{aligned} \text { Apical }--(\text { proximal }) \\
++(\text { distal })\end{aligned}\end{array}$ & $\begin{array}{l}\text { Density }= \\
\begin{aligned} \text { Type } & ++ \text { type I (apical and basal) } \\
& -\end{aligned}-\text { type II (apical and basal) }\end{array}$ \\
\hline$n \circ g \circ A^{-1-}$ & & $\begin{array}{l}\text { Basal }= \\
\text { Apical }+(\text { mid-distal })\end{array}$ & Density $=$ \\
\hline NogoA shRNA & $\begin{array}{l}\text { Length }= \\
\text { Complexity }=\end{array}$ & $\begin{array}{l}\text { Basal }= \\
\begin{aligned} \text { Apical } & - \text { (proximal) } \\
& + \text { (distal) }\end{aligned}\end{array}$ & $\begin{array}{l}\text { Density }= \\
\text { Type }=\end{array}$ \\
\hline NgR1 shRNA & $\begin{array}{l}\text { Length }++ \\
\underline{\text { Complexity }}++\end{array}$ & $\begin{array}{l}\text { Basal }= \\
\underline{\text { Apical }}++ \text { (middistal) }\end{array}$ & $\begin{array}{l}\text { Density }= \\
\begin{aligned} \text { Type } & ++ \text { type I (apical and basal) } \\
& -- \text { type II (apical and basal) })\end{aligned}\end{array}$ \\
\hline NogoA overexpression & & $\begin{array}{l}\text { Basal = } \\
\text { Apical - - (middistal) }\end{array}$ & $\begin{array}{l}\text { Density }= \\
\text { Type }=\end{array}$ \\
\hline
\end{tabular}

Underlining indicates $p<0.05$ or $p<0.01$. For single values, please refer to Results.

\section{Nogo-A neutralization affects dendritic spines}

Nogo-A is localized in the neuropil in the mature hippocampus, whereas its receptor $\mathrm{NgR} 1$ has been detected at synaptic contact sites (Wang et al., 2002). In ngrl knock-out mice, a shift in the spine type distribution in CA1 pyramidal neurons was observed without changes in spine number (Lee et al., 2008). However, a significant increase in dendritic spine density was shown in cortical pyramidal cells after stroke when an anti-Nogo-A antibody treatment was applied (Papadopoulos et al., 2002). These observations suggest that Nogo-A may regulate the formation or maintenance of dendritic spines. We therefore assessed whether loss of Nogo-A function, by acute neutralizing antibody treatment, resulted in altered dendritic spine density and/or morphology in CA1 and CA3 hippocampal neurons.

Although anti-Nogo-A antibody-treated CA1 cells showed a slightly lower and CA3 cells a marginally higher spine density than controls, we did not observe a significant change in total dendritic spine density either in CA1 (Fig. 2A, C, Table 1; supplemental Table S1, available at www.jneurosci.org as supplemental material) or CA3 (Fig. 2B,D, Table 1; supplemental Table S1, available at www.jneurosci.org as supplemental material). Similarly, a more detailed analysis of spine density in the different dendritic compartments (basal, midapical, and distal-apical) of CA1 and CA3 neurons treated with $11 \mathrm{C} 7$ antibody confirmed these trends again without significance (Fig. 2A, B, Table 1; supplemental Table S1, available at www.jneurosci.org as supplemental material).

Structural changes in the form, length, and width of dendritic spines are expected to exert physiologically relevant effects on the biochemical and electrical consequences of synaptic stimulation (Yuste et al., 2000). Therefore, we next compared the size and shape of dendritic spines in WT pyramidal neurons treated with Nogo-A blocking antibodies versus control hippocampal neurons. Because of the great variety of spine morphologies, we adopted a set of criteria to objectively classify spines (Harris et al., 1992; Koh et al., 2002; Zagrebelsky et al., 2005) (see Materials and Methods) and compared the proportion of different spine types in 11C7 Ab-treated versus control pyramidal neurons. We ob- served a significant difference in the distribution of type 2 (mushroom) spines of the CA1 midapical and basal compartment between mIgG1 control antibody-treated and fEGFP-expressing, not treated cells (supplemental Fig. 2, Table S3, available at www. jneurosci.org as supplemental material) $(p<0.05)$. Therefore, nontreated and mIgG1 control antibody-treated cells were not combined and the spine type distribution of $11 \mathrm{C} 7$ antibodytreated cells was compared with mIgG1 antibody-treated cells. Interestingly, this analysis again revealed only minor alterations in CA1 cells (Fig. $2 C^{\prime}$; supplemental Table S3, available at www. jneurosci.org as supplemental material). Only the proportion of type 1 (stubby) spines was in fact significantly higher in the most distal apical dendrite of $11 \mathrm{C} 7$ antibody-treated cells (Fig. 2C', Table 1; supplemental Table S3, available at www.jneurosci.org as supplemental material) ( $n=4$ cells, 1817 spines; $p<0.05$ ) compared with mIgG1-treated cells. No significant changes in the proportion of the different spine types could be observed for the rest of the dendritic tree (Fig. 2C'; supplemental Table S3, available at www.jneurosci.org as supplemental material). In contrast to CA1, dendritic spine shapes in CA3 pyramidal neurons were strongly altered by Nogo-A neutralization when compared with mIgG1 control antibodies (Fig. 2 $D^{\prime}$, Table 1; supplemental Table S3, available at www.jneurosci.org as supplemental material) (each $n=3$ cells, mIgG1 1498 spines; 11C7 1217 spines). We found a significantly higher percentage of type 1 (stubby) spines and a significantly lower percentage of type 2 (mushroom) spines in Nogo-A antibody-treated neurons (Fig. 2D, $D^{\prime}$, left; Table 1; supplemental Table S3, available at www.jneurosci.org as supplemental material) $(p<0.01)$. A more detailed analysis of spine shapes in the different dendritic compartments of CA3 cells (Fig. $2 D^{\prime}$ ) showed a highly significant increase in type 1 spines both for the midapical and basal dendrites of CA3 11C7 antibody-treated cells (Fig. $2 D^{\prime}$, Table 1; supplemental Table S3, available at www. jneurosci.org as supplemental material $)(p<0.01)$ as well as a decrease in type 2 spines in the same compartments (Fig. $2 D^{\prime}$, Table 1; supplemental Table S3, available at www.jneurosci.org as supplemental material) $(p<0.01)$. Furthermore, the proportion of type 1 spines was also increased in the most apical dendritic compartment of 11C7-treated cells (Fig. 2D', Table 1; supple- 
A

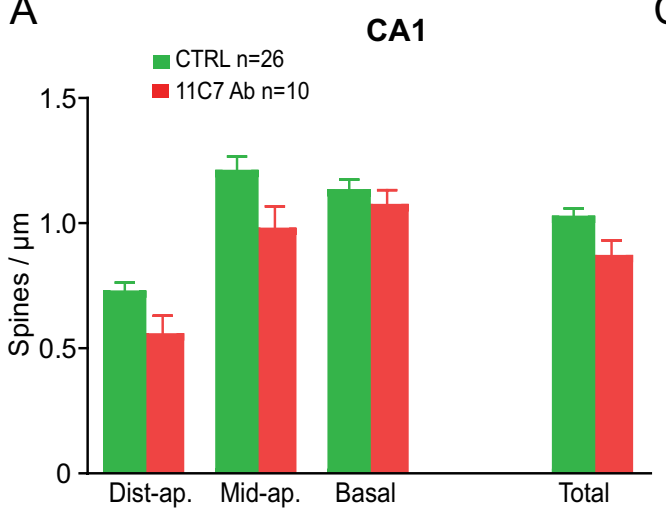

B

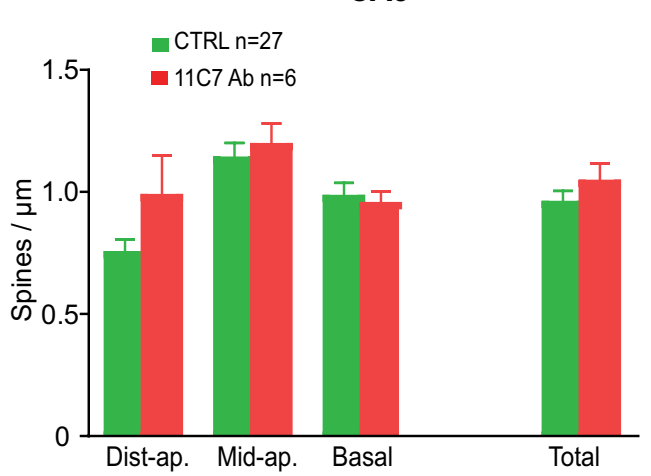

C

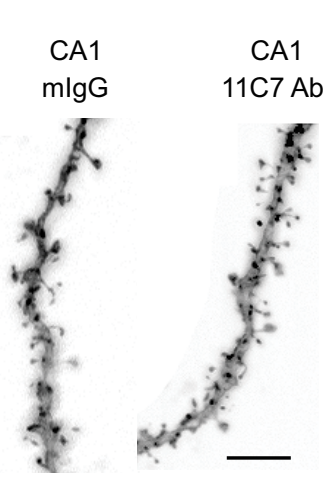

$D$

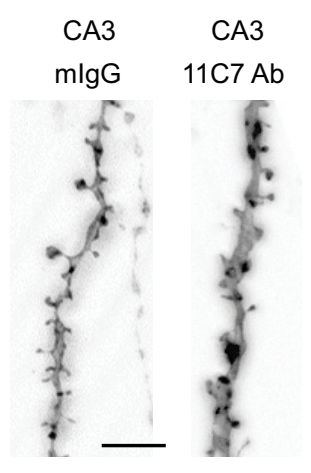

$C^{\prime}$
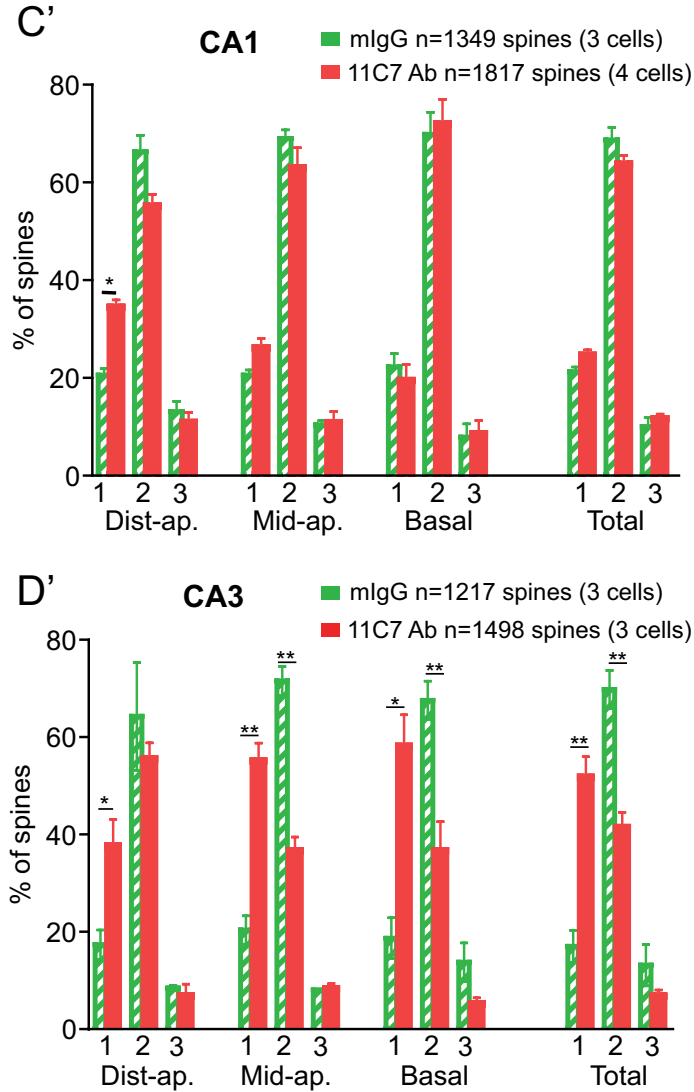

Figure 2. Nogo-A neutralization leads to a dendritic spine phenotype. $\boldsymbol{A}, \boldsymbol{B}$, Spine density count for CA1 and CA3 hippocampal neurons show no significant differences in spine density values between control and 11C7-treated neurons. Both total spine density and the density in the different dendritic compartments are shown. $\boldsymbol{C}$, High-magnification ApoTome image of a representative stack of apical dendrites of a mlgG1 (left) and 11C7 Ab-treated (right) CA1 pyramidal neuron. Scale bar, $10 \mu \mathrm{m}$. $\boldsymbol{C}^{\prime}$, The chart shows the proportions of the three spine types for mlgG1 control (green) and $11 \mathrm{C} 7 \mathrm{Ab}$ (red)-treated CA1 neurons plotted for the total neurons or separated between distal-apical, midapical, and basal compartments. In the distal apical dendritic compartment of $11 \mathrm{C7}$ Ab-treated CA1 neurons, the proportion of stubby spines (type I) is significantly higher than in control neurons. The asterisk indicates $p<0.05$. D, High-magnification ApoTome image of a representative stack of apical dendrites of a mlgG1 (left) and 11C7 Ab-treated (right) CA3 pyramidal neuron. Scale bar, $10 \mu \mathrm{m}$. $\boldsymbol{D}^{\prime}$, The chart shows the proportions of the three spine types for mlgG1 control (green) and $11 \mathrm{C} 7 \mathrm{Ab}$ (red)-treated CA3 neurons plotted for the total neuron or separated between distal-apical, midapical, and basal compartments. In all dendritic compartments as well as in the total count, the proportion of stubby spines (type I) is significantly higher, whereas the proportion of mushroom spines (type II) is significantly lower in $11 \mathrm{C7}$ Ab-treated neurons than in control neurons. ${ }^{*} p<0.05 ;{ }^{* *} p<0.01$. Error bars indicate SEM.

mental Table S3, available at www.jneurosci.org as supplemental material) $(p<0.05)$. No changes were observed for type 3 (thin) spines in any dendritic compartment of CA3 hippocampal neurons (Fig. 2D'; supplemental Table S3, available at www. jneurosci.org as supplemental material).

Together, these results demonstrate that Nogo-A influences the morphology of dendritic spines but not their number. Furthermore, the dendritic spines of CA3 pyramidal cell are more affected by the Nogo-A neutralization than those of CA1 cells, in line with our observations concerning dendritic complexity.

\section{Dendrite architecture and dendritic spine density in nogo- $A^{-/-}$hippocampal pyramidal cells}

As an alternative to the acute neutralization of Nogo-A by antibody treatment, we analyzed hippocampal slice cultures derived from nogo-A KO mice generated by homologous recombination as described by Simonen et al. (2003) and Dimou et al. (2006). When we qualitatively compared nogo- $A \mathrm{KO}$ pyramidal neurons with WT neurons, no apparent alterations in dendritic orientation or gross neuronal architecture could be observed, both for CA1 and CA3. Accordingly, we did not observe any significant differences in total complexity of both apical and basal dendrites between WT and nogo- $A$ KO-derived CA1 and CA3 pyramidal cells [CA1 (Fig. $3 A$, inset): apical, $p=0.75$; basal, $p=0.29$; WT, $n=29$; nogo- $A$ KO, $n=20$; CA3 (Fig. $3 C$, inset): apical, $p=0.77$; basal, $p=0.63$; WT, $n=20$; nogo- $A \mathrm{KO}, n=17]$. However, the Sholl analysis revealed a statistically significant increase in dendritic complexity in the middistal portion of the apical dendrite for both the CA1 and CA3 neurons (Fig. 3A, C, Table 1). Specifically, the apical dendrites of nogo- $A$ KO-derived CA1 pyramidal neurons showed a significantly higher dendritic complexity between 540 and $610 \mu \mathrm{m}$ from the soma (Fig. $3 A$, filled circles; Table 1$)(p<0.05)$. This area in vivo approximately corresponds to the stratum lacunosum-moleculare in which layer II entorhinal cortex axons terminate on dendrites of CA1 pyramidal neurons. The apical dendrites of nogo- $A$ KO CA3 pyramidal neurons showed a shift in dendrite complexity from the proximal to the middistal portion of the apical dendritic tree: although complexity was slightly reduced in the most proximal part of the apical dendritic tree (between 20 and $180 \mu \mathrm{m}$ ), it was significantly higher in nogo- $A$ KO than in WT neurons between 240 and 310 $\mu \mathrm{m}$ from the cell body (Fig. $3 C$, filled circles; Table 1$)(p<0.05)$. This area corresponds to the proximal portion of the stratum radiatum where mostly associational fibers and recurrent collaterals of CA3 axons form their synapses with the CA3 neuron apical dendrite. No significant changes in dendrite complexity were observed at the level of the basal dendrite of both CA1 and CA3 cells (Fig. $3 A, C$, open circles). 
We then further determined whether absence of nogo- $A$ in the knock-out mice resulted in altered dendritic spine density. Compared with fEGFP-labeled WT pyramidal cells, no significant differences were revealed in total synaptic density either in nogo-A KO-derived CA1 (Fig. $3 B)(n=$ 12) (Table 1; supplemental Table S1, available at www.jneurosci.org as supplemental material) and CA3 cells (Fig. 3D) $(n=12)$ (Table 1 ; supplemental Table S1, available at www.jneurosci.org as supplemental material). Moreover, for CA3 pyramidal neurons, we did not observe any significant difference in spine density in the different dendritic compartments (Fig. 3D) (CA3, apical dendrites) (supplemental Table S1, available at www. jneurosci.org as supplemental material). However, a significant reduction in dendritic spine density could be observed for the most distal portion of the apical dendrite of CA1 pyramidal cells (Fig. 3B) $(p<0.05)$. Interestingly, in the same portion of the apical dendrite, we observed a significant increase in dendrite complexity. No significant differences were observed in spine density in the midapical portion (Fig. 3B; supplemental Table S1, available at www.jneurosci.org as supplemental material) of the apical dendrite and in the basal dendrites (Fig. 3B; supplemental Table S1, available at www. jneurosci.org as supplemental material) of CA1 pyramidal cells.

A possible mechanism explaining the significant differences in the phenotypes observed in nogo- $A$ knock-out versus WT neurons treated with Nogo-A blocking antibodies is the upregulation of Nogo-B in the nogo-A KO. We therefore compared by Western blot analysis the Nogo-B expression levels in WT and nogo- $A$ KO hippocampi. Indeed, in agreement with previous studies (Simonen et al., 2003), we could observe a strong upregulation of Nogo- $\mathrm{B}$ in the nogo- $A \mathrm{KO}$ hippocampus (supplemental Fig. $5 A$, available at www.jneurosci.org as supplemental material). Moreover, to examine whether the mild phenotype observed in the nogo- $A$ mutant neurons could indeed be attributable to the upregulation of Nogo-B, we analyzed the dendritic structure of fEGFP/Nogo-B-overexpressing neurons. No significant differences in dendrite complexity were observed both for the basal and apical dendrites between fEGFP only and fEGFP-Nogo-B-overexpressing CA3 pyramidal neurons (supplemental Fig. $5 B, B^{\prime}$, available at www.jneurosci.org as supplemental material).

\section{Cell-autonomous versus}

receptor-mediated Nogo-A effects on the dendritic arborization of the hippocampal neuron

Nogo-A is present in oligodendrocytes and myelin surrounding the main axons of hippocampal pyramidal cells, but it is also endogenously expressed in the pyramidal neurons themselves and interneurons of the CA1-CA4 areas (Huber et al., 2002; Craveiro et al.,
2008). Nogo-A could thus signal from oligodendrocytes to neurons as well as from presynaptic to postsynaptic neurons or vice versa. In addition, Nogo-A could exert intracellular functions within the pyramidal cells. We therefore first addressed a possible cellautonomous role of Nogo-A in controlling dendritic architecture of pyramidal neurons by analyzing fEGFP-positive neurons cotransfected with a Nogo-A-specific shRNA in an otherwise WT hippocampus. We concentrated the analysis on CA3 pyramidal cells where the strongest effects of Nogo-A neutralizing antibodies had been seen. To test the hypothesis of a ligand-receptor-mediated mechanism of action of Nogo-A, we analyzed the morphology of CA3 hippocampal neurons after shRNA-mediated knockdown of the Nogo66 receptor NgR1.

In a first step, the specificity and efficacy of the RNAi plasmid targeting Nogo-A (Nogo-A shRNA) was tested by Western blot in the neuronal cell line B104 (Fig. 4A) as well as in PC12 cells (data not shown). Both cell lines express Nogo-A and -B endogenously. The pronounced Nogo-A band was downregulated in cells expressing the shRNA for Nogo-A but not in the control shRNA transfected cells (ctrl shRNA) (Fig. 4A). Importantly, the levels of Nogo-B in the same cells were not affected by the Nogo- 

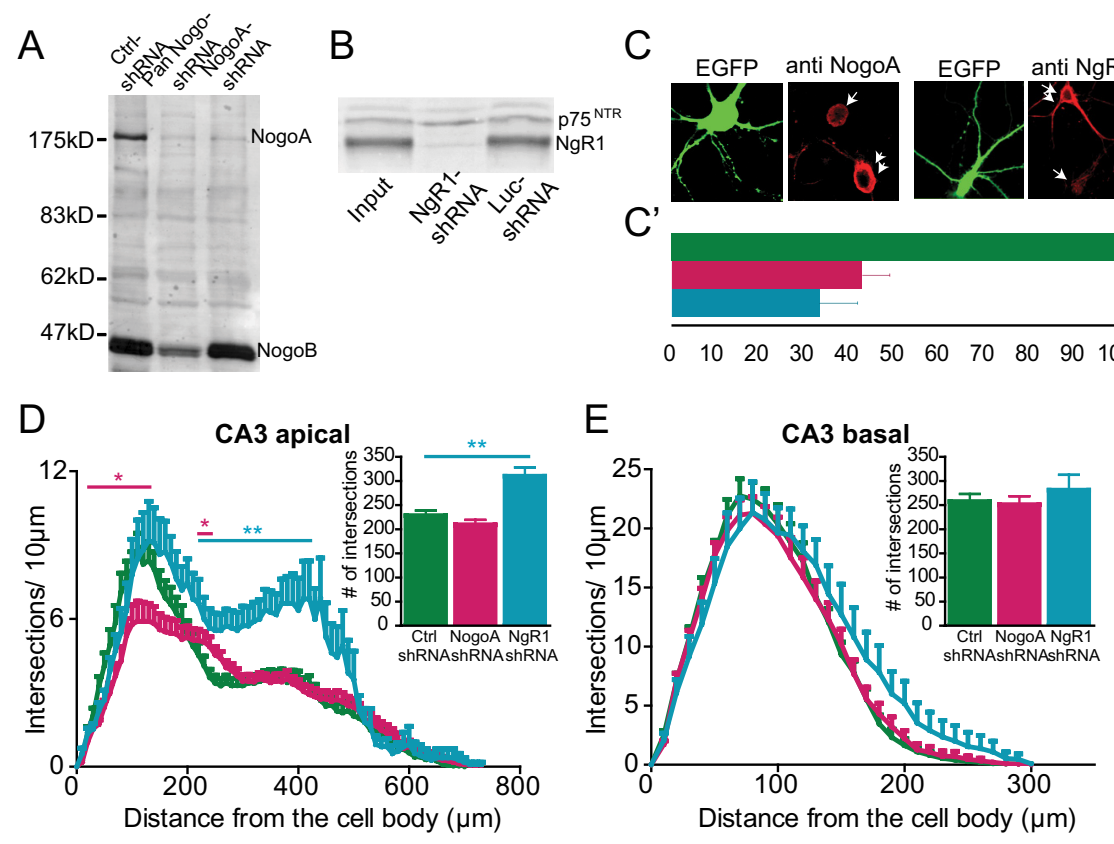

- Ctrl $n=30$ - NogoA shRNA $n=33-$ NgR1 shRNA $n=11$

Figure 4. Effect of Nogo-A/NgR1 downregulation on the hippocampal neurons dendritic arborization. $A$, Western blot from the neuronal cell line B104 demonstrating the specificity and efficacy of the RNAi plasmid targeting Nogo-A (Nogo-A shRNA). The Western blot shows a strong downregulation of Nogo-A specifically in cells expressing the shRNA for Nogo-A but not the control shRNA (ctrl shRNA). Furthermore, the levels of Nogo-B in the same cells are not affected by the expression of the Nogo-A-specific shRNA, whereas they are reduced after expression of a Pan-Nogo shRNA. $\boldsymbol{B}$, Western blot from HEK cells expressing both V5-tagged NgR1 and HA-tagged p75 NTR demonstrating the specificity and efficacy of the RNAi plasmid targeting NgR1 ( $\mathrm{NgR} 1 \mathrm{shRNA}$ ). Note that, although $\mathrm{NgR} 1$ shRNA-expressing cells strongly downregulated NgR1, no changes could be observed in the levels of $\mathrm{p} 75^{\mathrm{NTR}}$.C, $\boldsymbol{C}^{\prime}$, The micrographs show two examples of EGFP/Nogo-A shRNA (left)- and EGFP/NgR1 shRNA-expressing dissociated hippocampal neurons. The graph compares the fluorescence intensity measured in the cell body of shRNA-expressing neurons (arrow) relative to nontransfected neighbors (double arrows). The graph shows clearly lower fluorescence intensity in Nogo-A and EGFP/NgR1 shRNA-expressing neurons. D, Sholl analysis comparing the apical dendrites of ctrl shRNA, Nogo-A, and NgR1 shRNA-expressing CA3 pyramidal neurons. Note the lower complexity proximally in Nogo-A shRNA-expressing neurons and the higher complexity distally in NgR1 shRNA-expressing CA3 neurons. ${ }^{*} p<0.05$; ${ }^{* *} p<0.01$. The insets show the total dendritic of apical dendrites of ctrl, Nogo-A, or NgR1 shRNA-expressing CA3 pyramidal neurons. $\boldsymbol{E}$, Sholl analysis comparing the basal dendrites of ctrl shRNA, Nogo-A, and NgR1 shRNA-expressing CA3 pyramidal neurons. No differences in dendritic complexity between ctrl, Nogo-A, and NgR1 shRNA-expressing CA3 neurons can be observed. The insets show the total dendritic of basal dendrites of ctrl, Nogo-A, or NgR1 shRNA-expressing CA3 pyramidal neurons. Error bars indicate SEM.

A-specific shRNA, whereas they were reduced after expression of a Pan-Nogo shRNA (Fig. 4A). The specificity and efficacy of the RNAi plasmid targeting NgR1 (NgR1 shRNA) was tested by Western blot in HEK cells expressing both V5-NgR1 and HAp75 NTR. Although NgR1 shRNA-expressing cells strongly downregulated NgR1 no changes could be observed in the levels of p $75^{\text {NTR }}$ (Fig. $4 B^{\prime}$ ). The efficacy of the Nogo-A shRNA as well as the NgR1 shRNA was also tested in dissociated hippocampal neurons. Transfection was confirmed by the cytoplasmic expression of EGFP, whereas the levels of Nogo-A and NgR1 protein were analyzed by immunocytochemistry; fluorescence intensity was measured in the cell bodies of shRNA-expressing neurons (Fig 4C, arrows) relative to nontransfected cells (Fig. 4C, double arrows). We observed that, $8 \mathrm{~d}$ after shRNA transfection, Nogo-A was reduced to $40.3 \pm 5.8 \%$ (Fig. $4 C^{\prime}$ ) and $\mathrm{NgR} 1$ to $31.3 \% \pm 7.9$ when compared with neighboring nontransfected cells (Fig. $4 C^{\prime}$ ).

We then compared total dendritic complexity of CA3 pyramidal neurons in which Nogo-A was specifically downregulated to control shRNA-expressing cells: no significant differences in total complexity was observed for the apical dendrite (Fig. 4D, inset) (ctrl shRNA, $n=30$; Nogo-A shRNA, $n=33$ ). However, the Sholl analysis revealed a mild alteration, similar to the one induced by Nogo-A antibody treatment (Fig. 4D): a statistically significant decrease in dendritic complexity could be observed in the proximal portion (between 40 and 140 $\mu \mathrm{m})$ of the apical dendrite of Nogo-A shRNA-expressing cells (Fig. $4 D$, Table 1 ) $(p<0.05)$. In addition, although much less pronounced than for 11C7 Ab-treated cells, silencing of Nogo-A resulted in a significant increase of dendritic complexity in a limited part of the middistal portion of the apical dendrite (Fig. 4D, Table 1) $(p<0.05$ between 240 and $260 \mu \mathrm{m}$ ). No significant differences were observed both for total complexity and for the Sholl analysis between the basal dendrites of control and Nogo-A shRNA-expressing CA3 cells (Fig. $4 E$, Table 1).

A similar analysis was performed to compare the dendritic architecture of control shRNA-expressing CA3 pyramidal cells with cells expressing a specific shRNA for NgR1. Interestingly, a highly significant increase in dendritic complexity was found (Fig. $4 D$, inset) $(p<0.01$; ctrl shRNA, $n=$ 30; NgR1 shRNA, $n=11$ ). Furthermore, the Sholl analysis revealed a highly significant increase in complexity for the middistal portion (between 240 and $440 \mu \mathrm{m}$ ) of the apical dendrite of the cells downregulating NgR1 (Fig. 4D, Table 1) $(p<0.01)$. As for the Nogo-A shRNA-expressing cells, no significant differences were found both for total complexity and for the Sholl analysis between the basal dendrites of control and NgR1 shRNA-expressing CA3 cells (Fig. 4E, Table 1).

\section{Cell-autonomous versus receptor- mediated Nogo-A effects on dendritic spine number and shape in hippocampal neurons}

We then determined whether the downregulation of Nogo-A or $\mathrm{NgR} 1$ in single neurons resulted in altered dendritic spine density and/or morphology. To this aim, we first compared spine density in the CA3 pyramidal cells expressing either Nogo-A shRNAs (Fig. 5A) $(n=7)$ (supplemental Table S2, available at www. jneurosci.org as supplemental material) or NgR1 shRNAs (Fig. $5 A)(n=5)$ (supplemental Table S2, available at www.jneurosci. org as supplemental material) to control shRNA $(n=8)$ expressing CA3 pyramidal cells. No significant differences could be observed for total dendritic spine density as well as for the spine density within the different dendritic compartments (Fig. $5 A$, Table 1; supplemental Table S2, available at www.jneurosci. org as supplemental material).

We then analyzed the size and shape of dendritic spines in CA3 pyramidal neurons in which either Nogo-A or NgR1 were downregulated by the expression of specific shRNAs and compared the results to those obtained with control shRNA. We could not find any significant difference in spine type distribution between control and Nogo-A-shRNA-expressing CA3 hippocampal neurons (Fig. 5B, Table 1; supplemental Table S4, available at www.jneurosci.org as supplemental material) $(n=3$ cells; 1051 spines) both for the entire dendritic tree as well as for the specific dendritic compartments. Interestingly, however, the 


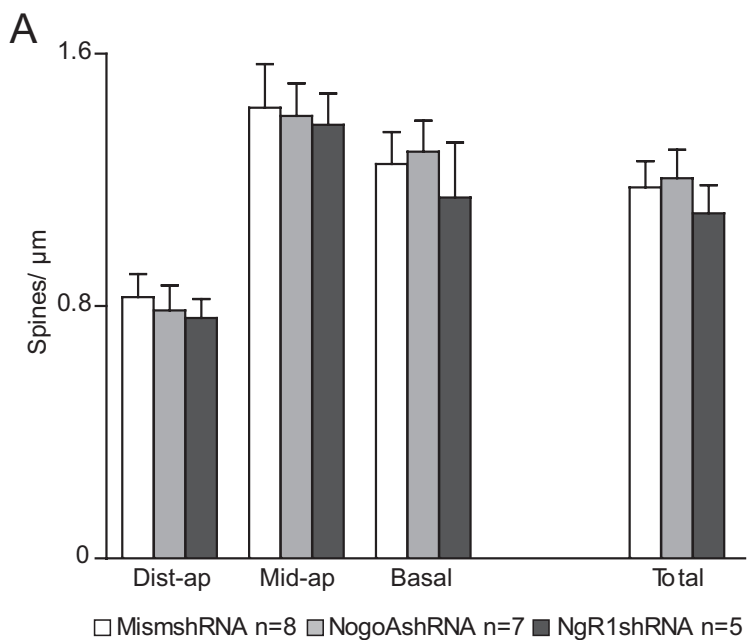

B

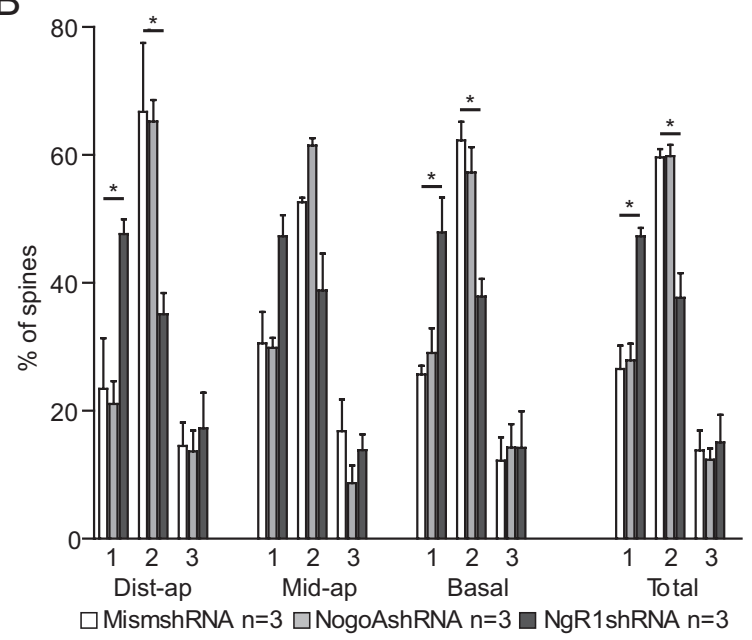

Figure 5. Effect of Nogo-A/NgR1 downregulation on the dendritic spines of the hippocampal neuron. $A$, Spine density counts for CA3 hippocampal neurons showing no significant differences in spine density values between control, Nogo-A, or NgR1 shRNA-expressing CA3 neurons. Both total spine density and the density in the different dendritic compartments are shown. $\boldsymbol{B}$, The chart shows the proportions of the three spine types for control, Nogo- $A$, or NgR1 shRNA-expressing CA3 neurons plotted for the total neurons or separated between distalapical, midapical, and basal compartments. Note that the spine type distribution of Nogo-A shRNA-expressing cells is not different from the one of control CA3 neurons. NgR1 shRNAexpressing cells show a significantly higher proportion of stubby spines (type I) and a significantly lower proportion of mushroom spines (type II) for the total neurons as well as for the distal-apical and basal dendritic compartments. The asterisk indicates $p<0.05$. Error bars indicate SEM.

spine type distribution of neurons expressing the NgR1 shRNA was significantly different from the one of control cells (Fig. $5 B$, Table 1; supplemental Table S4, available at www.jneurosci.org as supplemental material) ( $n=3$ cells; 1114 spines; $p<0.05$ ): we found a significantly higher percentage of type 1 (stubby) spines and a significantly lower percentage of type 2 (mushroom) spines in NgR1 shRNA-expressing CA3 neurons versus control shRNAexpressing cells (Fig. 5B, Table 1; supplemental Table S4, available at www.jneurosci.org as supplemental material) $(p<0.05)$. No significant changes could be observed for type 3 (thin) spines. An identical, highly significant shift in the distribution of type 1 and type 2 spines could be observed specifically in the most apical and basal dendritic compartments (Fig. 5B, Table 1; supplemental Table S4, available at www.jneurosci.org as supplemental material) $(p<0.05)$. Furthermore, in the midapical compartment of NgR1 shRNA-expressing cells the increase of type 1 and the decrease in type 2 spines was clearly detectable compared with control cells (Fig. 5B, Table 1; supplemental Table S4, available at www.jneurosci.org as supplemental material) $(p=0.055)$.

\section{Nogo-A gain-of-function experiments}

To further explore the role played by the neuronal expression of Nogo-A in regulating dendrite architecture, we first took a gainof-function approach by overexpressing myc-tagged Nogo-A in individual CA3 hippocampal neurons. Immunohistochemisty for the myc tag was used to distinguish fEGFP only from fEGFP/ Nogo-A-coexpressing neurons. The entire dendritic tree was positive for Nogo-A with a more intense labeling in the proximal compartments (data not shown). Qualitatively, CA3 neurons overexpressing Nogo-A did not show a profound alteration of the dendritic architecture when compared with fEGFP only expressing pyramidal neurons. Quantification of the total number of dendritic branches did not show any significant difference both for the apical and the basal dendrites of Nogo-A-overexpressing cells (supplemental Fig. $4 A, B$, inset, available at www.jneurosci. org as supplemental material) (fEGFP $n=20$, Nogo-A $n=10$; apical $p=0.09$, basal $p=0.43$ ). We then used the Sholl analysis to compare the apical dendrites of control versus Nogo-Aexpressing neurons. Interestingly, the apical dendrite of Nogo-Aoverexpressing CA3 cells showed a significant alteration of dendritic complexity opposite to the one observed after Nogo-A neutralization or downregulation (supplemental Fig. $4 A$, available at www.jneurosci.org as supplemental material). Specifically, in the middistal portion, complexity of Nogo-A-overexpressing cells was significantly lower than the one of control CA3 cells (supplemental Fig. 4A, available at www.jneurosci.org as supplemental material; Table 1) ( $p<0.05$ between 320 and $420 \mu \mathrm{m}$ from the soma), whereas in the proximal portion of the apical dendrite complexity was visibly, but not significantly, higher. No alterations in dendrite complexity could be observed for the basal dendrites of Nogo-Aoverexpressing cells (supplemental Fig. 4B, available at www. jneurosci.org as supplemental material; Table 1). Furthermore, in agreement with our observations in neurons in which Nogo-A was downregulated, no differences in spine density as well as in spine type distribution could be observed between fEGFP/Nogo-A- and fEGFP-expressing CA3 neurons (supplemental Fig. $4 B, B^{\prime}$, available at www.jneurosci.org as supplemental material).

In a second gain-of-function approach, we briefly incubated primary hippocampal neurons (DIV 25) with the Nogo-A- $\Delta 20$ fragment, an 18 aa peptide part of the Nogo-A-specific inhibitory domain (Oertle et al., 2003). Nogo-A- $\Delta 20$ strongly inhibits fibroblast spreading and neurite outgrowth (Oertle et al., 2003). The application of Nogo-A- $\Delta 20$ fragment was used to probe whether surface-mediated Nogo-A-specific signaling contributes to regulating the dendritic spine morphology in hippocampal neurons. Dendritic spines of Nogo-A- $\Delta 20$-treated hippocampal neurons look thinner and longer than those of control-treated neurons (supplemental Fig. $7 A, A^{\prime}$, available at www.jneurosci.org as supplemental material). We could not observe any significant difference in spine density between Nogo-A- $\Delta 20$ - and controltreated hippocampal neurons (supplemental Fig. $7 B$, available at www.jneurosci.org as supplemental material). Quantification of spine type proportion in Nogo-A- $\Delta 20$-treated neurons showed that, whereas stubby spines (type I) are significantly lower, mushroom spines (type II) are significantly higher than in controltreated neurons (supplemental Fig. 7C, available at www. jneurosci.org as supplemental material). The proportion of thin spines (type III) is equal in the two groups. 


\section{Role of Nogo-A in modulating length and complexity of CA3 pyramidal cell axons}

In addition to dendrites, manipulations of Nogo-A and its receptor NgR1 might also affect the axons of hippocampal pyramidal cells. We traced the axonal arbor with special attention to the CA3 recurrent collateral within the stratum oriens and stratum radiatum of the CA3 region. We first compared camera lucida reconstructions of control and Nogo-A antibody-treated CA3 axons (Fig. 6A). Although control CA3 neurons showed only few axonal branches within the stratum radiatum (Fig. 6A, left), Nogo-A antibody-treated CA 3 axons displayed a profuse branching especially in the distal portion of the stratum radiatum as well as in the stratum lacunosum-moleculare (Fig. $6 \mathrm{~A}$, right). No differences in axonal branching could be observed in the stratum oriens between control and Nogo-A antibody-treated neurons. After Nogo-A neutralization by antibody treatment (11c7) (Fig. $6 B$, insets; Table 1$)(n=12)$, we observed a significant increase in total length $(p<0.05)$ and in the number of branch points $(p<$ $0.05)$ of CA3 axons when compared with control cells $(n=22)$. Next, we performed a Sholl analysis to assess whether the observed increase in length and complexity after Nogo-A antibody treatment could be correlated to the phenotype observed at the dendrite level. A significant increase in the number of intersections of Nogo-A antibody-treated axons $(n=12)$ occurs specifically between 390 and $470 \mu \mathrm{m}$ from the cell body (Fig. 6 B, Table 1) $(p<0.05)$ when compared with control cells $(n=22)$, a distance approximately corresponding to the distal portion of the stratum radiatum.

To further elucidate the relative contribution of the cellautonomous versus receptor-mediated function of Nogo-A, we first examined axonal morphology of CA3 axons in which Nogo-A was downregulated by specific shRNA expression. We could not observe any significant difference between the axons of control and Nogo-A shRNA-expressing CA3 cells in total length, number of nodes, and Sholl analysis (Fig. 6C, Table 1) $(n=20)$. We then addressed a potential receptor-mediated function of Nogo-A by analyzing the axons of CA3 neurons expressing specific NgR1 shRNAs. The axons of CA3 neurons downregulating NgR1 show a significant increase in the length $(p<0.05)$ as well as an increased number of branching points $(p=0.8)$ when compared with the axons of control CA3 cells (Fig. 6D, inset; Table 1) $(n=10)$. Furthermore, by plotting axonal complexity relative to the distance from the cell body, we could observe that the axonal complexity in cells downregulating NgR1 is significantly higher than in control cells specifically corresponding to the middistal portion of CA3 apical dendrites (Fig. 6B, Table 1) $(p<0.05$ between 150 and $300 \mu \mathrm{m}$ from the cell body; $n=10$ ).

\section{Nogo-A and NgR1 expression pattern in vivo and in organotypic hippocampal cultures}

In agreement with the in vivo development (Huber et al., 2002; Meier et al., 2003), Nogo-A expression shifts from a primarily neuronal expression in young hippocampal organotypic cultures (5 DIV) to an oligodendrocyte and neuron expression in older ones (21 DIV) (Craveiro et al., 2008). Using in situ hybridization with a Nogo-A-specific probe, we could confirm a similar expression pattern for the Nogo-A mRNA in differentiated hippocampal organotypic cultures (Fig. 7A) where neuronal expression of Nogo-A mRNA was seen within the pyramidal cell layer of both the CA1 and CA3 regions. Interestingly, the level of Nogo-A mRNA was markedly higher in CA3 than in CA1 (Fig. 7A). The specificity of the Nogo-A probe was tested on age-matched hippocampal organotypic cultures derived from nogo- $A$ knock-out
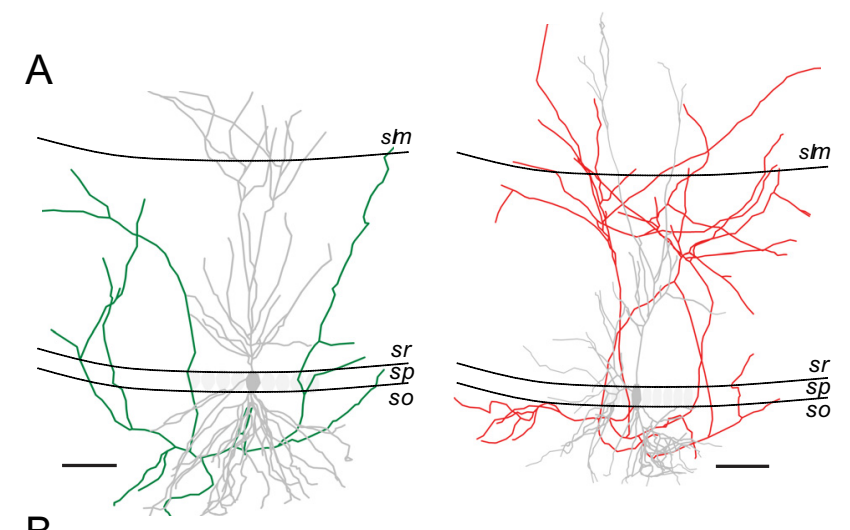

B

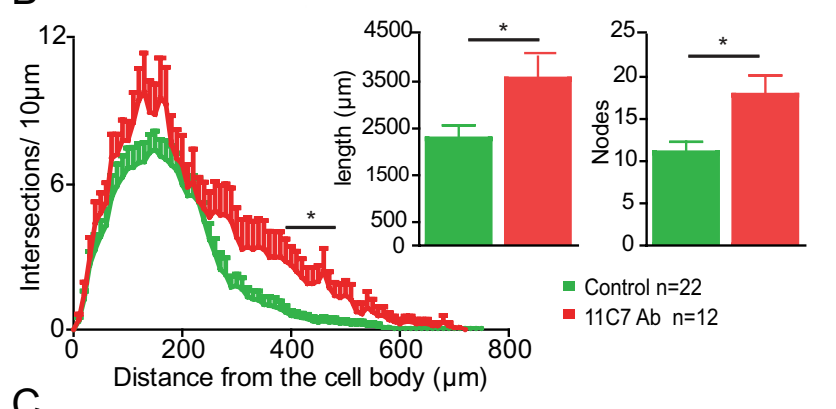

C

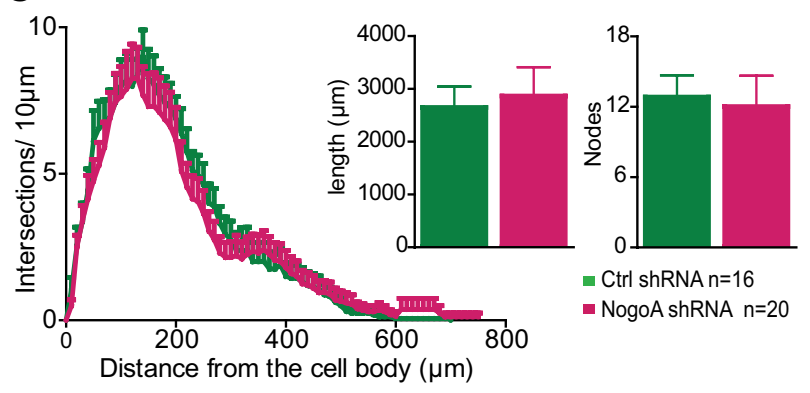

D

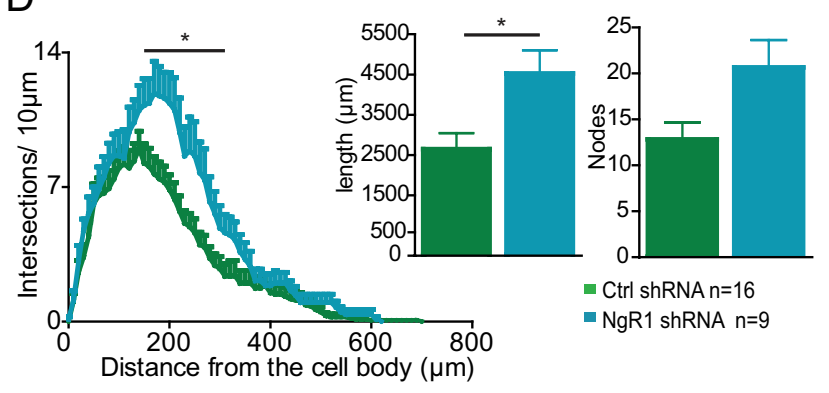

Figure 6. Nogo-A modulates length and complexity of CA3 pyramidal cell axons. A, Two camera lucida drawings show the axons of control (left) and $11 C 7$ Ab-treated CA3 hippocampal pyramidal neurons. Scale bars, $100 \mu \mathrm{m}$. $\mathrm{sm}$, Stratum lacunosum-moleculare; $\mathrm{Sr}$, stratum radiatum; sp, stratum pyramidale; $\mathrm{so}$, stratum oriens. $B$, Sholl analysis comparing the complexity of the axons of control versus $11 C 7 \mathrm{Ab}$-treated $C A 3$ neurons. 11C7 Ab-treated CA3 neurons show a significantly higher complexity than control axons. The asteriskindicates $p<0.05$. Theinsets show thetotal length (left) and number of nodes (right) for control and $11 C 7$ $\mathrm{Ab}$-treated $\mathrm{CA} 3$ neurons. Note the significantly higher length and number of nodes in the $11 \mathrm{CAb}$-treated CA3 neurons than in controls. C, Sholl analysis comparing the complexity of the axons of control versus Nogo-A shRNA-expressing CA3 neurons. Nogo-A shRNA-expressing CA3 neurons show no significant differencein complexity when compared with control axons. The insets show the total length (left) and number of nodes (right) for control and Nogo-A shRNA-expressing CA3 neurons. No significant difference in length and number of nodes can be detected in Nogo-A shRNA-expressing CA3 neurons when compared with the controls. D, Sholl analysis comparing the complexity of the axons of control versus NgR1 shRNA-expressing CA3 neurons. NgR1 shRNA-expressing CA3 neurons show a significantly higher complexity than control axons. Theasteriskindicates $p<0.05$. Theinsets show the total length (left) and number of nodes (right) for control and NgR1 shRNA-expressing CA3 neurons. Note the significantly higher length and the increased number of nodes in the NgR1 shRNA-expressing CA3 neurons than in controls. Error bars indicate SEM. 

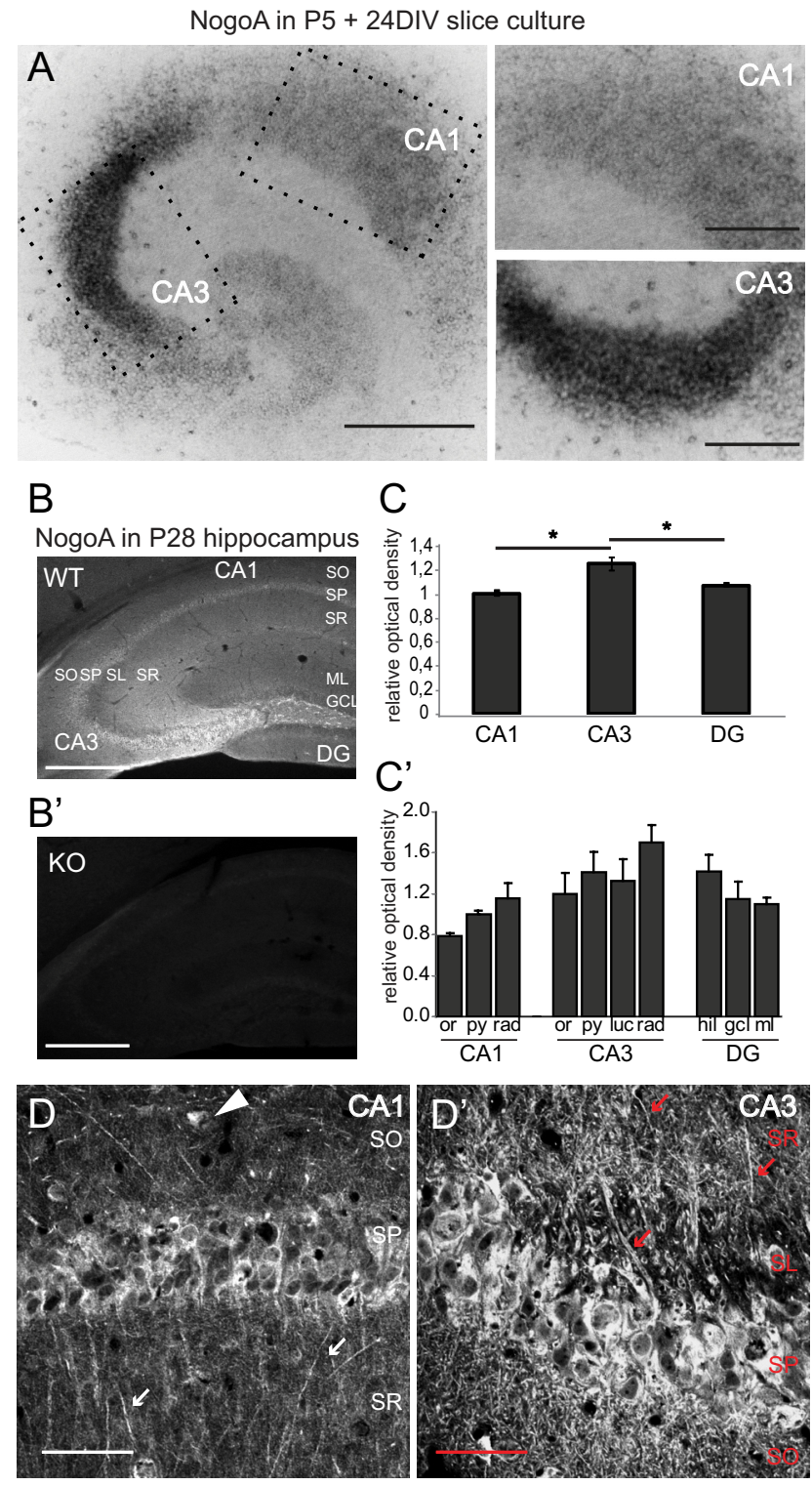

Figure 7. Expression pattern of Nogo-A in the mouse hippocampus.A, Micrographs showing in situ hybridization for Nogo-A mRNA in 24 DIV mouse hippocampal organotypic cultures. Note Nogo-A mRNA expression both in the CA1 and CA3 regions of the hippocampus. Scale bar, $1 \mathrm{~mm}$. The two higher magnification micrographs shown on the right depict two close-ups of the CA1 and CA3 regions. Note the higher levels of Nogo-A mRNA expression in CA3 than in CA1. $\boldsymbol{B}$, Micrographs showing the immunohistochemistry for Nogo-A in thin sections of the P28 mouse hippocampus in WT and nogo-A KO mice. Note the evident Nogo-A expression in the pyramidal cell layer of many CA1 and CA3 hippocampal neurons as well as in the stratum radiatum of CA3. C, The graph shows the relative optical density of Nogo-A staining within the different regions of the of the P28 WT mouse hippocampus. Note the significantly higher Nogo-A expression in CA3 versus $C A 1$ and the dentate gyrus. ${ }^{*} p<0.05$. $C^{\prime}$, The graph shows the relative optical density of Nogo-A staining within the different layers of CA1, CA3, and DG in P28 WT mouse hippocampus. $D, D^{\prime}$, The two higher magnification micrographs depict two close-ups of the CA1 and $C A 3$ regions respectively showing a stronger Nogo-A staining in CA3 than in CA1. Note that several dendrites of pyramidal cells are clearly labeled for Nogo-A (arrows). Scale bar, $100 \mu \mathrm{m}$. Error bars indicate SEM. SO, Stratum oriens; SP, stratum pyramidale; SL, stratum lucidum; SR, stratum radiatum; $\mathrm{ML}$, molecular layer; $\mathrm{GCL}$, granule cell layer; DG, dentate gyrus.

mice (Simonen et al., 2003) in which we could not detect any specific hybridization signal (data not shown).

To address the in vivo relevance of the differential distribution of Nogo-A between CA1 and CA3, sections of P28 WT (Fig. 7B) or nogo- $A \mathrm{KO}$ (Fig. $7 B^{\prime}$ ) hippocampus were stained with a poly- clonal anti-Nogo-A antiserum (AS “Laura”) (Oertle et al., 2003). Neuronal expression of Nogo-A was seen in the pyramidal cell layer of both WT CA1 and CA3 (Fig. $7 B, D, D^{\prime}$ ) but not in the nogo- $A \mathrm{KO}$. As observed in the organotypic hippocampal cultures, the Nogo-A level in CA3 was notably higher than in CA1 and in the dentate gyrus (Fig. $7 B$ ). We then quantified the relative optical density of the Nogo-A staining and observed a significantly higher intensity in CA3 than in CA1 and dentate gyrus (CA1, $1 \pm 0.07$; CA3, $1.4 \pm 0.11$; and DG, $1.2 \pm 0.09$ ) (Fig. 7C) $(n=4 ; p<0.05)$. Furthermore, although Nogo-A expression was generally higher in all the layers of CA3, the highest levels were observed within the stratum radiatum (CA1, $1.2 \pm 0.15$; CA3, $1.7 \pm 0.17 ; p=0.055$ ) (Fig. $7 C^{\prime}$ ). Indeed, at a higher resolution, we could observe a strong Nogo-A staining not only in oligodendrocytes (Fig. 7D, arrowhead) but also within the cell body and the dendrites of CA1 (Fig. 7D, arrows) and especially CA3 pyramidal cells (Fig. $7 D^{\prime}$, arrows).

The strong alterations in dendrite complexity and spine type distribution observed in CA3 pyramidal cells expressing NgR1 shRNAs prompted us to analyze the expression pattern of $\mathrm{NgR} 1$ in differentiated organotypic hippocampal cultures. Wang et al. (2002) previously reported marked levels of NgR1 protein in pyramidal cells and granule cells of the mature hippocampus. Accordingly, using in situ hybridization with an NgR1-specific probe, we could observe a strong expression of NgR1 mRNA within the pyramidal cell layer of both the CA1 and CA3 regions as well as in the dentate gyrus of DIV 24 hippocampal organotypic cultures (Fig. $8 \mathrm{~A}$ ). Immunohistochemistry performed on sections of WT P28 hippocampus confirmed the expression of $\mathrm{NgR} 1$ in the CA1 and CA3 regions as well as in the dentate gyrus in vivo (Fig. $8 \mathrm{~B}$ ). We then quantified the relative optical density of the NgR1 staining and observed equal levels of $\mathrm{NgR} 1$ expression within CA1 and CA3 and significantly higher levels within the dentate gyrus (CA1, $1.49 \pm 0.15$; CA3, $1.39 \pm 0.1$; and DG, $1.8 \pm$ 0.16; CA3 vs DG, $p<0.05$ ) (Fig. $8 C$ ). Although in CA1 NgR1 levels were especially high within the stratum oriens and stratum radiatum, in CA3 the highest expression was observed in the stratum lucidum and stratum radiatum (Fig. $8 C^{\prime}$ ).

The expression of the NgR1 protein was also investigated in sections of P28 nogo- $A$ KO hippocampus and compared with age-matched WT sections (supplemental Fig. 6A, $A^{\prime}$, available at www.jneurosci.org as supplemental material). We quantified the relative optical density of the $\mathrm{NgR} 1$ staining and observed in the nogo- $A$ KO hippocampus a strong reduction of NgR1 immunoreactivity in all areas of the hippocampus (supplemental Fig. $6 B$, available at www.jneurosci.org as supplemental material) but especially pronounced in all layers of the dentate gyrus (supplemental Fig. $6 B^{\prime}$, available at www.jneurosci.org as supplemental material). Furthermore, a visible, although not significant, reduction in NgR1 protein in the nogo-A KO versus the WT hippocampus was also observed by Western blot (supplemental Fig. $6 C, C^{\prime}$, available at www.jneurosci.org as supplemental material).

Finally, to more clearly define the cellular localization of Nogo-A and NgR1 within the hippocampus, we repeated the immunohistochemistry applying a very efficient antigen unmasking protocol. As previously shown (Fig. 7D, $D^{\prime}$ ), Nogo-A immunoreactivity was observed in oligodendrocytes (Fig. 9A, $B$, arrowheads) and in the pyramidal cells of both CA1 and CA3 (Fig. 9A, $B$, arrows). In the latter, Nogo-A staining was present within the cell body as well as along the dendrites (Fig. 9A, $B$, arrows). It is noteworthy that, especially in the CA3 region, the apical dendrite of pyramidal cells was strongly labeled both in the stratum lucidum and in the stratum radiatum (Fig. 9B, arrows). 
A

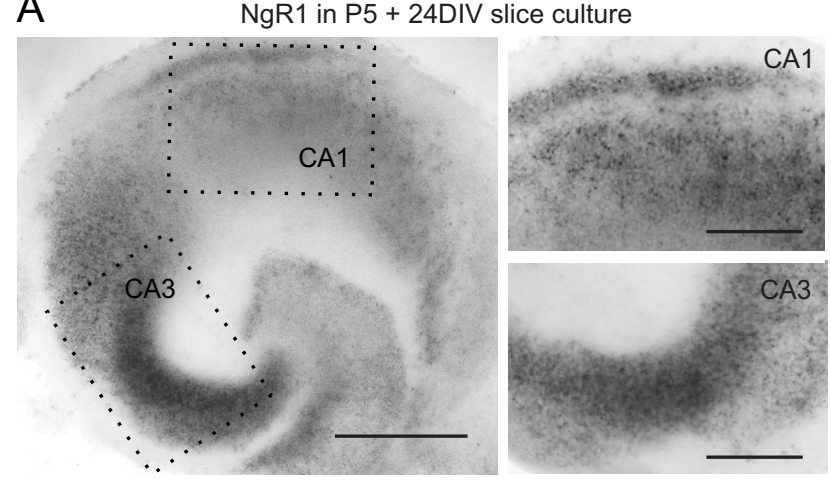

B
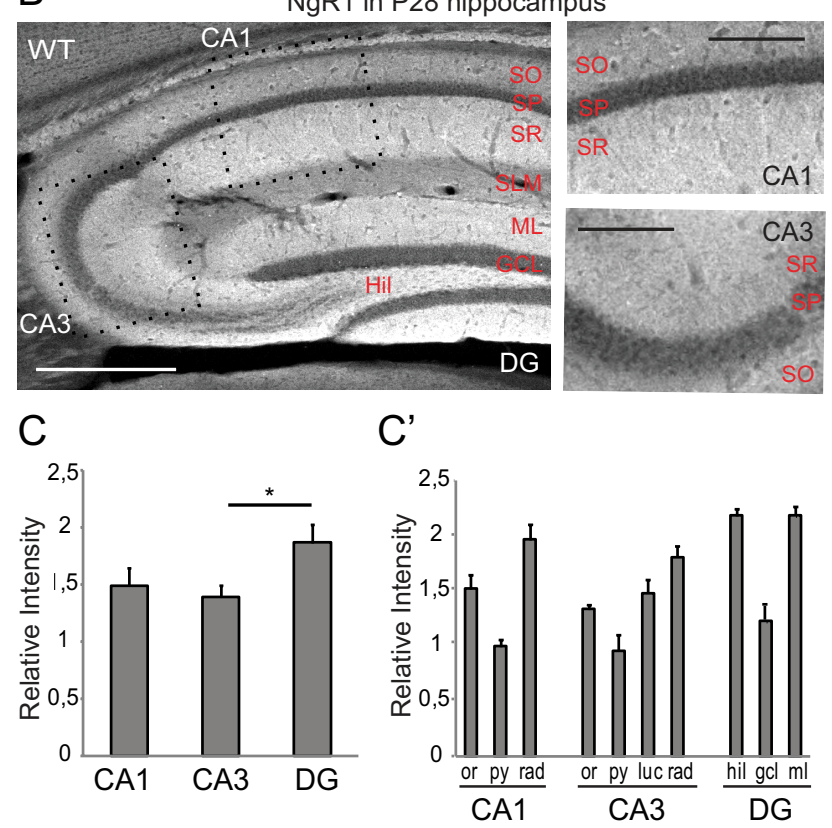

Figure 8. Expression pattern of $\mathrm{NgR1}$ in the mouse hippocampus. $A$, Micrographs showing in situ hybridization for NgR1 mRNA in 24 DIV mouse hippocampal organotypic cultures. Note NgR1 mRNA expression both in the CA1 and CA3 regions of the hippocampus. Scale bar, $1 \mathrm{~mm}$. The two higher magnification micrographs shown on the right depict two close-ups of the CA1 and $C A 3$ regions. $B$, Micrograph showing the immunohistochemistry for $\mathrm{NgR} 1$ in thin sections of P28 WT mouse hippocampus. Note NgR1 expression in the neuropil in the stratum oriens and radiatum of $\mathrm{CA} 1$ and $C A 3$. The two higher magnification micrographs shown on the right depict two close-ups of the CA1 and CA3 regions. C, The graph shows the relative intensity of $\mathrm{NgR} 1$ staining within the different regions of the P28 WT mouse hippocampus. Note the equal levels of $\mathrm{NgR} 1$ expression in $\mathrm{CA} 3$ and $\mathrm{CA} 1$ and the higher levels in the dentate gyrus. ${ }^{*} p<0.05 . \mathrm{C}^{\prime}$, The graph shows the relative intensity of $\mathrm{NgR} 1$ staining within the different layers of $\mathrm{CA} 1, \mathrm{CA} 3$, and DG in P28 WT mouse hippocampus. Error bars indicate SEM. SO, Stratum oriens; SP, stratum pyramidale; SR, stratum radiatum; SLM, stratum lacunosum-moleculare; ML, molecular layer; GCL, granule cell layer; Hil, hilus; DG, dentate gyrus; or, stratum oriens; py, stratum pyramidale; luc, stratum lucidum; rad, stratum radiatum; hil, hilus; gcl, granule cell layer; ml, molecular layer.

The NgR1 immunohistochemistry revealed a punctate staining most prominent in the stratum oriens and the stratum radiatum of CA1 and CA3 (Fig. $9 A^{\prime}, B^{\prime}$ ) suggestive of a synaptic localization, as previously described for the cerebral cortex (Wang et al., 2002). In the CA3 region, NgR1 staining was observed especially along the profiles of the pyramidal cell apical dendrites (Fig. 9 ${ }^{\prime}$, arrows).

\section{Discussion}

Major work has been done to describe the role of Nogo-A as an inhibitor of axonal regeneration and sprouting after CNS injury
(Schwab, 2004). However, its physiological role in the mature CNS remains puzzling. To address this question, we investigated whether interfering with Nogo-A expression and signaling alters neuronal architecture in organotypic hippocampal slice cultures. Our results (summarized in Table 1) show that (1) Nogo-A antibody treatment induces major alterations in the dendrite structure, spine type distribution, and axon morphology of hippocampal neurons; (2) downregulation of Nogo-A in individual neurons replicates only part of the dendritic alterations; (3) downregulation of $\mathrm{NgR} 1$, however, reproduces most of the dendritic, the axonal, and the spine type changes induced by Nogo-A neutralization. Together, our results demonstrate that Nogo-A modulates the growth potential of dendrites and axons of uninjured hippocampal neurons both via a cell-autonomous and a receptor-mediated mechanism.

We show that interfering with Nogo-A/NgR1 signaling induces major rearrangements in the architecture of uninjured hippocampal neurons. Nogo-A antibody treatment in the mature intact CNS was shown to induce a transitory sprouting of corticospinal fibers associated with enhanced expression of growthrelated genes (Bareyre et al., 2002) and the aberrant growth of intact Purkinje axons into the granular layer (Buffo et al., 2000). By tracing individual axons of CA3 neurons, after Nogo-A neutralization, we observed a significant increase in axonal length and complexity confirming the general increase in axonal growth reported by Craveiro et al. (2008) in the CA3 area of hippocampal organotypic cultures. Our data indicate that Nogo-A regulates the growth potential of intact axons and suggest that Nogo-A is involved in restricting plasticity to defined CNS areas and blocking axonal sprouting at unwanted sites, thus contributing to maintaining the connection specificity established during development. Accordingly, in mutant mice missing NgR1 (McGee et al., 2005) or PirB (Atwal et al., 2008), ocular dominance plasticity is maintained at all ages (Syken et al., 2006), suggesting that Nogo-A receptor signaling consolidates the neural circuitry. The data presented here confirm and expand this view describing a significant remodeling not only of axons but also at dendrites in uninjured hippocampal neurons. This is especially relevant as learning processes in the adult brain entail changes in the strength and in the structure of neuronal connections, including synapse formation/elimination and remodeling of axons as well as dendrites (Chklovskii et al., 2004). Remodeling of mature dendritic arborization on Nogo-A neutralization was described in cortical pyramidal neurons after an ischemic lesion (Papadopoulos et al., 2006) suggesting that Nogo-A acts as a stop signal also for dendritic growth in the injured CNS. We observed significant dendritic changes in uninjured hippocampal neurons treated with Nogo-A neutralizing antibody pointing to a new physiological role of Nogo-A in controlling the stability of intact dendritic arborizations in the adult brain.

By interfering with Nogo-A/NgR1 signaling, we observed much stronger alterations in CA3 than in CA1 hippocampal neurons. This is in agreement with the significantly higher levels of Nogo-A protein, in vivo, and of Nogo-A mRNA, in hippocampal organotypic cultures, in CA3 compared with CA1.

CA3 pyramidal neurons are not only the source of the Schaffer collateral pathway to CA1 but also of several local axon collaterals arborizing in the stratum radiatum (Sik et al., 1993; Li et al., 1994). We report here an increased complexity of the CA3 recurrent collaterals at a distance from the cell body matching the increase in dendrite complexity. Indeed, the observed dendritic and axonal changes occur within the same layer, approximately corresponding to the stratum radiatum. Together with an in- 

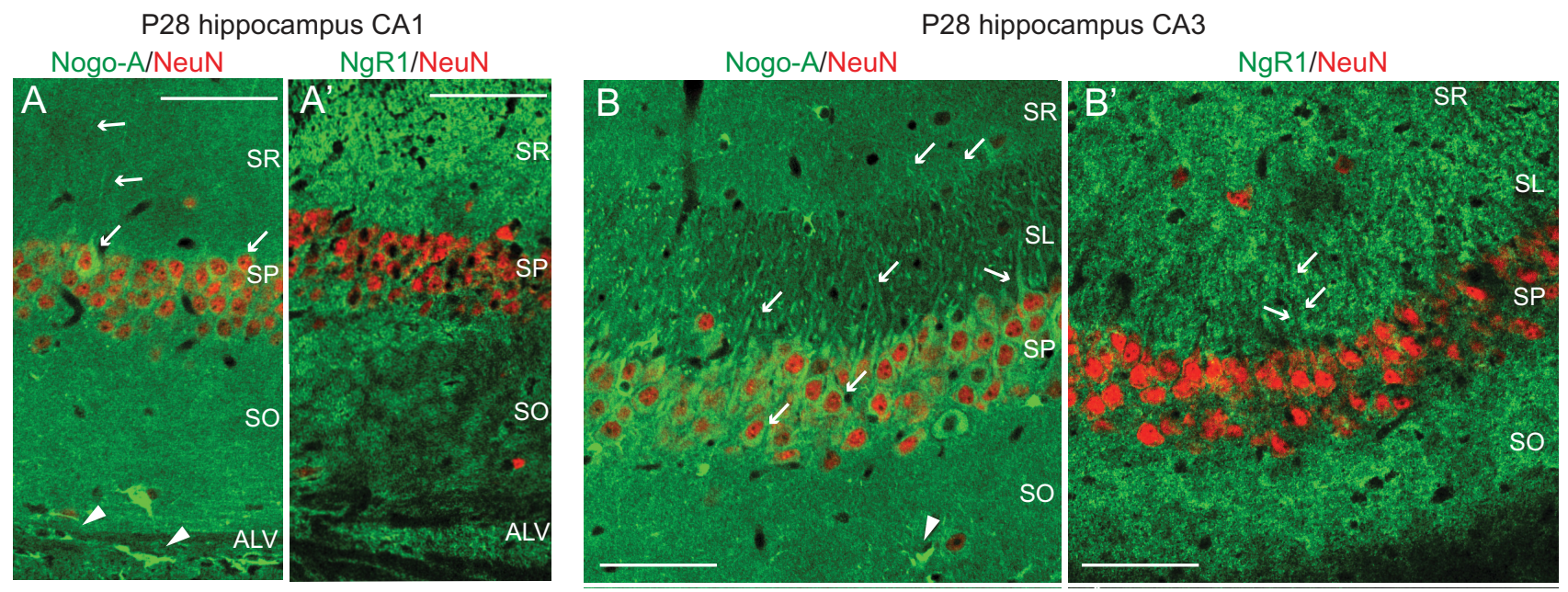

Figure 9. Subcellular localization of Nogo-A and NgR1 in the mature mouse hippocampus. A shows the expression pattern of Nogo-A in the CA1 area of P28 WT hippocampal thin sections. Nogo-A is labeled in green, and the neuronal cell bodies are labeled for NeuN in red. Scale bar, $100 \mu \mathrm{m}$. Please note for Nogo-A the positive oligodendrocytes and pyramidal neurons in the stratum oriens and stratum radiatum. $\boldsymbol{A}^{\prime}$ shows the expression pattern of $\mathrm{NgR} 1$ in the CA1 area of P28 WT hippocampal thin sections. $\mathrm{NgR1}$ is labeled in green and the neuronal cell bodies are labeled for NeuN in red. Scale bar, $100 \mu \mathrm{m}$. Please note the $\mathrm{NgR1}$, the punctate labeling in the stratum oriens and stratum radiatum. $\boldsymbol{B}$ and $\boldsymbol{B}^{\prime}$ show the expression pattern of Nogo-A and NgR1 protein in the $\mathrm{CA} \mathrm{3}$ area of P28 WT hippocampal thin sections, respectively. Nogo-A and NgR1 are labeled in green, and the neuronal cell bodies are labeled for NeuN in red. Scale bar, $100 \mu \mathrm{m}$. Please note for Nogo-A the positive oligodendrocytes and many pyramidal neurons (including their dendrites) and for NgR1 the punctate labeling in the stratum oriens, stratum lucidum, and stratum radiatum. SR, Stratum radiatum; SP, stratum pyramidale; SO, stratum oriens; SL, stratum lucidum; ALV, alveus.

crease in the complexity of CA1 basal dendrites, targeted by the Schaffer collaterals, this indicates a tight link between the axonal and the dendritic phenotype. As CA3 axons are myelinated and both CA3 and granule cells of the dentate gyrus express Nogo-A, the primary effect of its neutralization could be on the axons while dendrites would react to the axonal changes. However, Nogo-A might also directly act on CA3 dendrites, a view supported by the dendritic localization of Nogo-A in CA3 neurons and by its role in remodeling the dendrites of developing mitral cells of the olfactory bulb (Richard et al., 2005).

Papadopoulos et al. (2006) reported a significant increase in spine density in neurons of the intact sensory-motor cortex when Nogo-A neutralization followed a contralateral ischemic lesion. We could not observe changes in spine density, possibly because of differences between the uninjured and the injured brain (e.g., neurotrophin receptor expression). Likewise, in the hippocampus of ngr 1 mutant mice, spine density is comparable with wildtype levels (Lee et al., 2008). Nonetheless, the effect of Nogo-A neutralization might result in changes of spine shapes and dynamics and become visible only during time-lapse experiments. Indeed, we observed a significant reduction in type 2 (mushroom) and an increase in type 1 (stubby) spines, indicating a less mature and more plastic phenotype (Harris et al., 1992; Matsuzaki et al., 2004). Lee et al. (2008) describe in ngrl mutant mice a similar shift in the spine type. Taken together, structural plasticity of axons and dendrites is maintained longer if Nogo-A/NgR1 signaling is neutralized or genetically eliminated.

In differentiated organotypic hippocampal cultures, Nogo-A is expressed both by oligodendrocytes and CA3 pyramidal neurons (Craveiro et al., 2008). To distinguish the role of Nogo-A within the analyzed neuron (cell-autonomous) from an environmental, receptor-mediated activity, we compared the effect of an overall Nogo-A neutralization to the downregulation of Nogo-A or NgR1 within individual CA3 neurons. NgR1 downregulation replicates a major portion of the Nogo-A-dependent alterations, suggesting that they are indeed attributable to the suppression of Nogo-A/NgR1 signaling. This hypothesis is supported by the cell surface localization of both Nogo-A (Dodd et al., 2005) and NgR1 (Wang et al., 2002). Moreover, we show a marked expression of Nogo-A within the dendrites of hippocampal pyramidal neurons, especially within the stratum radiatum. The NgR1 punctate staining we observed in the stratum oriens, lucidum, and radiatum suggests a possible synaptic localization of the receptor in the hippocampus as previously proposed for the cerebral cortex (Wang et al., 2002). Finally, we show that a brief application of the soluble Nogo-A- $\Delta 20$ peptide induces opposite spine type alterations as the Nogo-A neutralization (supplemental Fig. 7, available at www.jneurosci.org as supplemental material), indicating that Nogo-A influences dendritic spine morphology via a non-cell-autonomous mechanism.

Signaling elicited by Nogo-A negatively influences neuronal cytoskeleton dynamics by modulating the activity of small GTPases of the Rho family (Niederöst et al., 2002; Hsieh et al., 2006; Montani et al., 2009). RhoA and Rac are indeed crucial for the maintenance and reorganization of dendritic spines as well as branches (Nakayama et al., 2000; Tashiro et al., 2000). Whether it is Nogo-A localized on neurons or on oligodendrocytes, or both, that interacts with neuronal receptors and accounts for the extrinsic effects on structural stability is currently not known. Downregulation of Nogo-A within individual CA3 neurons induced a significant decrease in dendrite complexity in the proximal portion of the apical dendrite. On the contrary, overexpression of Nogo-A induced a reverse alteration suggesting that Nogo-A might control dendrite branching also via a cellautonomous mechanism. A large proportion of Nogo-A localizes to the endoplasmic reticulum (ER), according to the presence of a C-terminal ER retention signal, but its functions in the ER remain poorly defined (Oertle and Schwab, 2003; Voeltz et al., 2006; Teng and Tang, 2008). However, the cell surface expression at synaptic sites of Nogo-A and NgR1 (Wang et al., 2002; Lee et al., 2008) raises the interesting hypothesis that Nogo-A could signal bidirectionally from postsynapse to presynapse (and back) as previously described for the ephrins (Murai and Pasquale, 2003). 
The analysis of dendrite architecture in nogo- $A$ knock-out neurons reproduced the phenotype observed after Nogo-A neutralization, however less pronounced. This pattern also occurs in in vivo models of spinal cord injury in which the functional neutralization of both Nogo-A and NgR1 proved to be more efficient in promoting regeneration than deleting the respective genes (Teng and Tang, 2005). Indeed, we could show that, whereas NgR1 was downregulated (supplemental Fig. 6, available at www. jneurosci.org as supplemental material), Nogo-B was upregulated in the hippocampus of nogo- $A \mathrm{KO}$ mice (supplemental Fig. 5 , available at www.jneurosci.org as supplemental material). However, the overexpression of Nogo-B did not affect dendrite morphology (supplemental Fig. 5, available at www.jneurosci. org as supplemental material), indicating that Nogo-B does not compensate or contribute to the phenotype of the nogo- $A$ mutant.

Experience-dependent structural changes at the level of dendritic spines and boutons are important aspects of plasticity in the adult CNS. Still, the large-scale organization of axons and dendrites in several areas of the intact brain shows a remarkable stability (Holtmaat and Svoboda, 2009). These observations indicate the necessity for molecules regulating the stability of mature neuronal networks at the end of development, especially in highly plastic regions like the hippocampus. Our results demonstrate that Nogo-A constitutively controls the architecture of neurons in the intact hippocampus mainly via a receptormediated mechanism. We suggest that Nogo-A thereby could play a crucial role in modulating the balance between plasticity and stability of the mature circuitry in the intact hippocampus, thus ensuring the necessary level of stability in an ever-changing neuronal network.

\section{References}

Aloy EM, Weinmann O, Pot C, Kasper H, Dodd DA, Rülicke T, Rossi F, Schwab ME (2006) Synaptic destabilization by neuronal Nogo-A. Brain Cell Biol 35:137-156.

Atwal JK, Pinkston-Gosse J, Syken J, Stawicki S, Wu Y, Shatz C, TessierLavigne M (2008) PirB is a functional receptor for myelin inhibitors of axonal regeneration. Science 322:967-970.

Bareyre FM, Haudenschild B, Schwab ME (2002) Long-lasting sprouting and gene expression changes induced by the monoclonal antibody IN-1 in the adult spinal cord. J Neurosci 22:7097-7110.

Brummelkamp TR, Bernards R, Agami R (2002) A system for stable expression of short interfering RNAs in mammalian cells. Science 296:550-553.

Buffo A, Zagrebelsky M, Huber AB, Skerra A, Schwab ME, Strata P, Rossi F (2000) Application of neutralizing antibodies against NI-35/250 myelinassociated neurite growth inhibitory proteins to the adult rat cerebellum induces sprouting of uninjured Purkinje cell axons. J Neurosci 20:2275-2286.

Caroni P, Schwab ME (1988) Two membrane protein fractions from rat central myelin with inhibitory properties for neurite growth and fibroblast spreading. J Cell Biol 106:1281-1288.

Chen MS, Huber AB, van der Haar ME, Frank M, Schnell L, Spillmann AA, Christ F, Schwab ME (2000) Nogo-A is a myelin-associated neurite outgrowth inhibitor and an antigen for monoclonal antibody IN-1. Nature 403:434-439.

Chklovskii DB, Mel BW, Svoboda K (2004) Cortical rewiring and information storage. Nature 431:782-788.

Craveiro LM, Hakkoum D, Weinmann O, Montani L, Stoppini L, Schwab ME (2008) Neutralization of the membrane protein Nogo-A enhances growth and reactive sprouting in established organotypic hippocampal slice cultures. Eur J Neurosci 28:1808-1824.

Dimou L, Schnell L, Montani L, Duncan C, Simonen M, Schneider R, Liebscher T, Gullo M, Schwab ME (2006) Nogo-A-deficient mice reveal strain-dependent differences in axonal regeneration. J Neurosci 26:5591-5603.

Dodd DA, Niederoest B, Bloechlinger S, Dupuis L, Loeffler JP, Schwab ME (2005) Nogo-A, -B, and -C are found on the cell surface and interact together in many different cell types. J Biol Chem 280:12494-12502.
Fournier AE, GrandPre T, Strittmatter SM (2001) Identification of a receptor mediating Nogo-66 inhibition of axonal regeneration. Nature 409: 341-346.

Gianola S, Savio T, Schwab ME, Rossi F (2003) Cell-autonomous mechanisms and myelin-associated factors contribute to the development of Purkinje axon intracortical plexus in the rat cerebellum. J Neurosci 23:4613-4624.

Harris KM, Jensen FE, Tsao B (1992) Three-dimensional structure of dendritic spines and synapses in rat hippocampus (CA1) at postnatal day 15 and adult ages_-implications for the maturation of synaptic physiology and long-term potentiation. J Neurosci 12:2685-2705.

Holtmaat A, Svoboda K (2009) Experience-dependent structural synaptic plasticity in the mammalian brain. Nat Rev Neurosci 10:647-658.

Holz A, Schaeren-Wiemers N, Schaefer C, Pott U, Colello RJ, Schwab ME (1996) Molecular and developmental characterization of novel cDNAs of the myelin-associated/oligodendrocytic basic protein. J Neurosci 16: 467-477.

Hsieh SH, Ferraro GB, Fournier AE (2006) Myelin-associated inhibitors regulate cofilin phosphorylation and neuronal inhibition through LIM kinase and Slingshot phosphatase. J Neurosci 26:1006-1015.

Huber AB, Weinmann O, Brösamle C, Oertle T, Schwab ME (2002) Patterns of Nogo mRNA and protein expression in the developing and adult rat and after CNS lesions. J Neurosci 22:3553-3567.

Huber AB, Kolodkin AL, Ginty DD, Cloutier JF (2003) Signaling at the growth cone: ligand-receptor complexes and the control of axon growth and guidance. Annu Rev Neurosci 26:509-563.

Hunt D, Mason MR, Campbell G, Coffin R, Anderson PN (2002) Nogo receptor mRNA expression in intact and regenerating CNS neurons. Mol Cell Neurosci 20:537-552.

Josephson A, Widenfalk J, Widmer HW, Olson L, Spenger C (2001) NOGO mRNA expression in adult and fetal human and rat nervous tissue and in weight drop injury. Exp Neurol 169:319-328.

Kapfhammer JP, Schwab ME (1994a) Inverse patterns of myelination and GAP-43 expression in the adult CNS: neurite growth inhibitors as regulators of neuronal plasticity? J Comp Neurol 340:194-206.

Kapfhammer JP, Schwab ME (1994b) Increased expression of the growthassociated protein GAP-43 in the myelin-free rat spinal cord. Eur J Neurosci 6:403-411.

Koh IY, Lindquist WB, Zito K, Nimchinsky EA, Svoboda K (2002) An image analysis algorithm for dendritic spines. Neural Comput 14:1283-1310.

Lee H, Raiker SJ, Venkatesh K, Geary R, Robak LA, Zhang Y, Yeh HH, Shrager P, Giger RJ (2008) Synaptic function for the Nogo-66 receptor NgR1: regulation of dendritic spine morphology and activity-dependent synaptic strength. J Neurosci 28:2753-2765.

Li XG, Somogyi P, Ylinen A, Buzsáki G (1994) The hippocampal CA3 network: an in vivo intracellular labeling study. J Comp Neurol 339:181-208.

Liebscher T, Schnell L, Schnell D, Scholl J, Schneider R, Gullo M, Fouad K, Mir A, Rausch M, Kindler D, Hamers FP, Schwab ME (2005) Nogo-A antibody improves regeneration and locomotion of spinal cord-injured rats. Ann Neurol 58:706-719.

Liu BP, Cafferty WB, Budel SO, Strittmatter SM (2006) Extracellular regulators of axonal growth in the adult central nervous system. Philos Trans R Soc Lond B Biol Sci 361:1593-1610.

Lom B, Cohen-Cory S (1999) Brain-derived neurotrophic factor differentially regulates retinal ganglion cell dendritic and axonal arborization in vivo. J Neurosci 19:9928-9938.

Matsuzaki M, Honkura N, Ellis-Davies GC, Kasai H (2004) Structural basis of long-term potentiation in single dendritic spines. Nature 429:761-766.

McAllister AK (2000) Cellular and molecular mechanisms of dendrite growth. Cereb Cortex 10:963-973.

McGee AW, Yang Y, Fischer QS, Daw NW, Strittmatter SM (2005) Experience-driven plasticity of visual cortex limited by myelin and Nogo receptor. Science 309:2222-2226.

Meier S, Bräuer AU, Heimrich B, Schwab ME, Nitsch R, Savaskan NE (2003) Molecular analysis of Nogo expression in the hippocampus during development and following lesion and seizure. FASEB J 17:1153-1155.

Mingorance A, Fontana X, Solé M, Burgaya F, Ureña JM, Teng FY, Tang BL, Hunt D, Anderson PN, Bethea JR, Schwab ME, Soriano E, del Río JA (2004) Regulation of Nogo and Nogo receptor during the development of the entorhino-hippocampal pathway and after adult hippocampal lesions. Mol Cell Neurosci 26:34-49.

Mingorance-Le Meur A, Zheng B, Soriano E, del Río JA (2007) Involvement 
of the myelin-associated inhibitor Nogo-A in early cortical development and neuronal maturation. Cereb Cortex 17:2375-2386.

Montani L, Gerrits B, Gehrig P, Kempf A, Dimou L, Wollscheid B, Schwab ME (2009) Neuronal Nogo-A modulates growth cone motility via RhoGTP/LIMK1/cofilin in the unlesioned adult nervous system. J Biol Chem 284:10793-10807.

Murai KK, Pasquale EB (2003) "Eph" ective signaling: forward, reverse and crosstalk. J Cell Sci 116:2823-2832.

Nakayama AY, Harms MB, Luo L (2000) Small GTPases Rac and Rho in the maintenance of dendritic spines and branches in hippocampal pyramidal neurons. J Neurosci 20:5329-5338.

Niederöst B, Oertle T, Fritsche J, McKinney RA, Bandtlow CE (2002) Nogo-A and myelin-associated glycoprotein mediate neurite growth inhibition by antagonistic regulation of RhoA and Rac1. J Neurosci 22:10368-10376.

Oertle T, Schwab ME (2003) Nogo and its paRTNers. Trends Cell Biol 13:187-194.

Oertle T, van der Haar ME, Bandtlow CE, Robeva A, Burfeind P, Buss A, Huber AB, Simonen M, Schnell L, Brösamle C, Kaupmann K, Vallon R, Schwab ME (2003) Nogo-A inhibits neurite outgrowth and cell spreading with three discrete regions. J Neurosci 23:5393-5406.

Papadopoulos CM, Tsai SY, Alsbiei T, O'Brien TE, Schwab ME, Kartje GL (2002) Functional recovery and neuroanatomical plasticity following middle cerebral artery occlusion and $\mathrm{IN}-1$ antibody treatment in the adult rat. Ann Neurol 51:433-441.

Papadopoulos CM, Tsai SY, Cheatwood JL, Bollnow MR, Kolb BE, Schwab ME, Kartje GL (2006) Dendritic plasticity in the adult rat following middle cerebral artery occlusion and Nogo-A neutralization. Cereb Cortex 16:529-536.

Peters A, Kaiserman-Abramof IR (1969) Small pyramidal neuron of rat cerebral cortex-synapses upon dendritic spines. Z Zellforsch Mikrosk Anat 100:487-506.

Richard M, Giannetti N, Saucier D, Sacquet J, Jourdan F, Pellier-Monnin V (2005) Neuronal expression of Nogo-A mRNA and protein during neurite outgrowth in the developing rat olfactory system. Eur J Neurosci 22:2145-2158.

Schwab ME (2004) Nogo and axon regeneration. Curr Opin Neurobiol 14:118-124.

Schwab ME, Schnell L (1991) Channeling of developing rat corticospinal tract axons by myelin-associated neurite growth inhibitors. J Neurosci 11:709-721.

Sholl DA (1953) Dendritic organization in the neurons of the visual and motor cortices of the cat. J Anat 87:387-406.

Sik A, Tamamaki N, Freund TF (1993) Complete axon arborization of a single CA3 pyramidal cell in the rat hippocampus, and its relationship with postsynaptic parvalbumin-containing interneurons. Eur J Neurosci 5:1719-1728.
Simonen M, Pedersen V, Weinmann O, Schnell L, Buss A, Ledermann B, Christ F, Sansig G, van der Putten H, Schwab ME (2003) Systemic deletion of the myelin-associated outgrowth inhibitor Nogo-A improves regenerative and plastic responses after spinal cord injury. Neuron 38:201-211.

Stoppini L, Buchs PA, Muller D (1991) A simple method for organotypic cultures of nervous tissue. J Neurosci Methods 37:173-182.

Syken J, Grandpre T, Kanold PO, Shatz CJ (2006) PirB restricts oculardominance plasticity in visual cortex. Science 313:1795-1800.

Tashiro A, Minden A, Yuste R (2000) Regulation of dendritic spine morphology by the rho family of small GTPases: antagonistic roles of Rac and Rho. Cereb Cortex 10:927-938.

Teng FY, Tang BL (2005) Why do Nogo/Nogo-66 receptor gene knockouts result in inferior regeneration compared to treatment with neutralizing agents? J Neurochem 94:865-874.

Teng FY, Tang BL (2008) Cell autonomous function of Nogo and reticulons: the emerging story at the endoplasmic reticulum. J Cell Physiol 216:303-308.

Tyler WJ, Pozzo-Miller LD (2001) BDNF enhances quantal neurotransmitter release and increases the number of docked vesicles at the active zones of hippocampal excitatory synapses. J Neurosci 21:4249-4258.

Voeltz GK, Prinz WA, Shibata Y, Rist JM, Rapoport TA (2006) A class of membrane proteins shaping the tubular endoplasmic reticulum. Cell 124:573-586.

Wang X, Chun SJ, Treloar H, Vartanian T, Greer CA, Strittmatter SM (2002) Localization of Nogo-A and Nogo-66 receptor proteins at sites of axonmyelin and synaptic contact. J Neurosci 22:5505-5515.

Wiessner C, Bareyre FM, Allegrini PR, Mir AK, Frentzel S, Zurini M, Schnell L, Oertle T, Schwab ME (2003) Anti-Nogo-A antibody infusion 24 hours after experimental stroke improved behavioral outcome and corticospinal plasticity in normotensive and spontaneously hypertensive rats. J Cereb Blood Flow Metab 23:154-165.

Xie FY, Woodle MC, Lu PY (2006) Harnessing in vivo siRNA delivery for drug discovery and therapeutic development. Drug Discov Today 11:67-73.

Yuste R, Bonhoeffer T (2001) Morphological changes in dendritic spines associated with long-term synaptic plasticity. Annu Rev Neurosci 24:1071-1089.

Yuste R, Bonhoeffer T (2004) Genesis of dendritic spines: insights from ultrastructural and imaging studies. Nat Rev Neurosci 5:24-34.

Yuste R, Majewska A, Holthoff K (2000) From form to function: calcium compartmentalization in dendritic spines. Nat Neurosci 3:653-659.

Zagrebelsky M, Holz A, Dechant G, Barde YA, Bonhoeffer T, Korte M (2005) The p75 neurotrophin receptor negatively modulates dendrite complexity and spine density in hippocampal neurons. J Neurosci 25:9989-9999. 